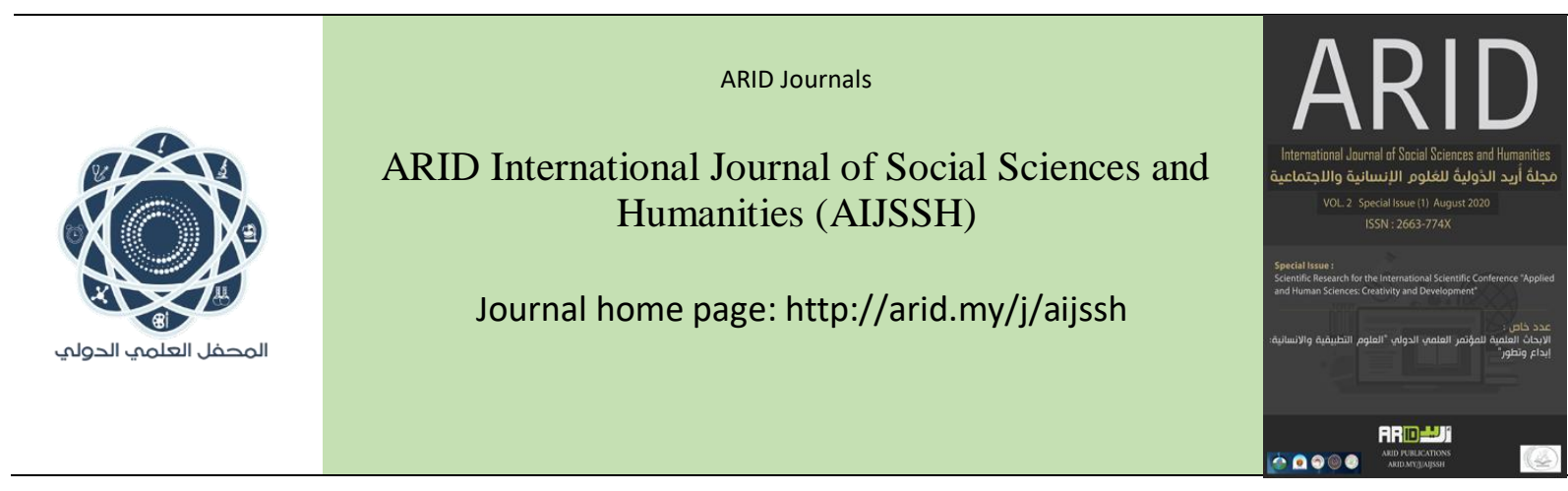

$$
\begin{aligned}
& \text { مَجلةُ أُريل اللَّوليةٌ للعُلورج الإنسانية والإجتماعية } \\
& \text { المجلد الثاني ،العدد الخاص ، آب } 2020 \text { م }
\end{aligned}
$$

\title{
Natural Reserves to develop Eco-Tourism and Urban Sustainability in Investing Karbala Governorate
}

Hanan hussain drewil

The Ministry of Higher Education Scientific Research University

Geographical division- College of Basic Education- Al Mustansiriya University

\author{
استثمار المحميات الطبيعية لتنمية السياحة البيئية والاستدامة الحضرية \\ في محافظة كربلاء \\ م. حنان حسين دريول \\ وزارة التعليم العالي والبحث العلمي- قسم الجغر افيةـ كلية التربية الأساسية ـالجامعة المستتصرية
}

hananhussan75@gmail.com

arid.my/0004-7077

https://doi.org/10.36772/arid.aijssh.2020.s.214 


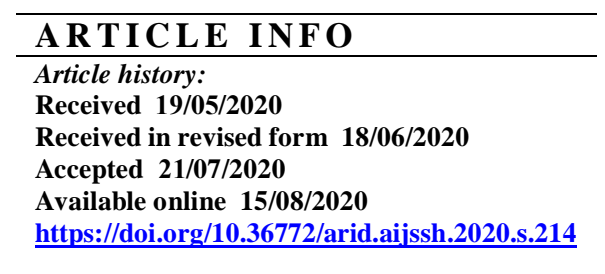

\begin{abstract}
The idea of establishing reserves clearly emerged in the modern era as a result of exposure to environmental balance, biological diversity and the global heritage of damages, and accordingly the protected areas became occupying approximately 5\% of the globe's spaces, so interest in setting up natural reserves began by inviting countries and international organizations to invite through studies and conferences to Preserving environmental systems and limiting the behavior of unjust people who are using methods leading to the degradation of many natural resources and in many cities where there are qualifications to establish natural reserves for the development of eco-tourism and in the light of this our research deals Natural data in Iraq, specifically the province of Karbala, the subject of our research that offer a lot of resources to the degradation and depletion therefore, this research is an attempt to discuss ways to establish nature reserves and its role in the maintenance and development of tourism and biodiversity, especially as the province of Karbala, which is characterized by geographical location and climate is replete with diverse biological.
\end{abstract}




\section{الملخص}

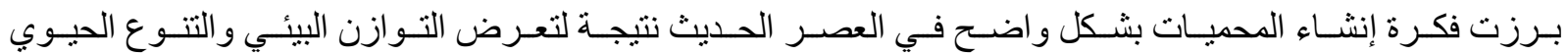

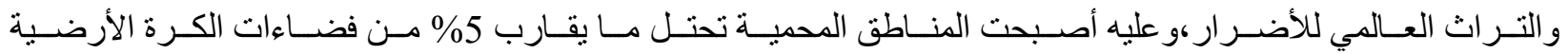

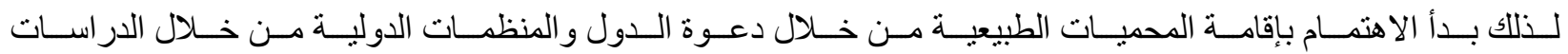

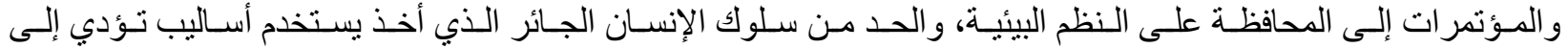

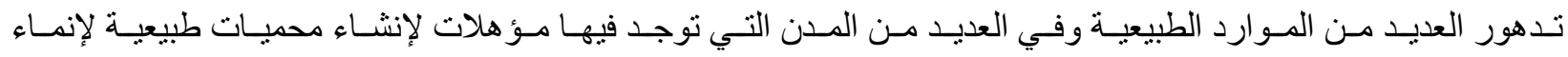

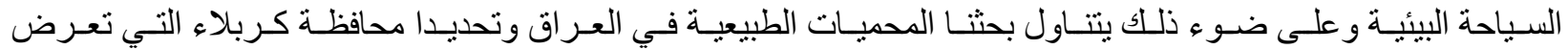

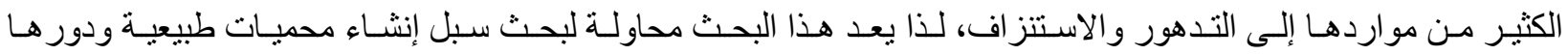

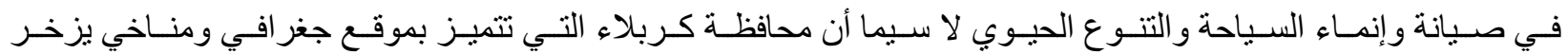
بتنوع بايلوجي

الكلمات المفتاحية: محميات طبيعية، سياحة بيئية ، توزيع جغر افي، الإمكانيات السياحية، استر اتيجية تطوير المحميات 
تتحدد مشكلة البحث بالتساؤل التالي: لماذا يتم الاعتماد على السياحة الدينية في محافظة كربلاء المتمثلة بالعتبات المقدسة فقط

$$
\text { و عدم توسيعها إلى السياحة البيئية؟ }
$$

أما فرضية البحث: فتنطلق من أن محافظة كربلاء التي نزخر ببيئة بايلوجية متنوعة يمكن استغلالها بإنشاء محميات طبيعية تسهم بتفعيل السياحة البيئية في المحافظة .

هدف البحث: يسعى البحث إلى توجيه الاهتمام بتطوير و إنشاء المحميات الطبيعية في محافظة كربلاء وتحويلها إلى مناطق سياحية بيئية وبمو اصفات خاصة سيكون وسيلة جذب جيدة للسائحين والمستكثفين والبعثات العلمية وتقوم بتعميق مساهمة السياحة البيئية بتوسيع القاعدة الاقتصادية وتحقيق التنمية المستدامة. المبحث الأول :المحميات الطبيعية ( مفهومها، أهميتها، أهدافها، معايير ها، فائدها ) بالرغم من كون الإنسان هو المسيطر على أحداث التغيرات التي تحصل في البيئة الطبيعية، لكنه المسؤول عن حمايتها أيضاً، ومن هذا المنطلق يظهر لدينا مصطلحات مهمة وهي حماية البيئة، وعلى وجه الخصوص البيئة الطبيعية والأحياء فيها وتسمى ( موقع التراث الطبيعي ).

إن تأسيس و إدارة المحميات الطبيعية يعد من أهم طرق المحافظة على المصادر الطبيعية في العالم كي نحافظ على وفرتها الآن وفي المستقبل، فالمفهوم الحديث لحماية الطبيعة هو الصيانة والاستغلال الحكيم والأمثل لمصادر الأرض ويرتكز هذا المفهوم في عنصرين اثنين هما: [11]

2.

و هذان العنصر ان وردا في الماضي فالحماية وردت من خلال تشريع قانوني في الهند، والمسح الدقيق للتخطبط في إدارة المصادر ورد في بريطانيا، وتؤكد الاستر اتيجية العالمية لحماية البيئة الطبيعية أن حماية الطبيعة ومصادر ها هي من ضروريات التنمية المستدامة ويمكن تحقيق هذه الحماية عن طريق ما يلي : 
التاكد من أن استقلال الإنسان للأنواع والنظم البيئية هو استغلال غير جائز مما يسمح لهذه الأنواع بالاستمرار[9]

حيث تعرف المحميات الطبيعية بأنها مناطق محددة الأبعاد الجغر افية تفرض عليها الحماية بموجب قو انين وأنظمة خاصة بهدف حماية محتو اها من حيو انات وطيور ونباتات ولقد زاد عدد المناطق المحمية على المستوى العالمي زيادة كبيرة بلغ نحو 478 ) منطقة في عام 1970، ارتفع إلى ما يقارب ( 10000 ) منطقة حالياً وتغطي هذه المحميات ما يقارب من 6\% من [6] [مساحة الأرض. [6] أما المحميات الطبيعية النباتية فهي نفس المحميات الطبيعية العامة ولكنها مخصصة في حماية الأنواع و الأصناف النباتية من أثجار ونباتات باختلاف أنو اعها و أحجامها .

\section{مفهوم المحميات الطبيعية :}

مما لاشك فيه، إن الحياة بشقيها النباتي والحيواني وجدت قبل نشوء الإنسان وتطوره لذلك نستطيع القول بإن هذه الحياة كانت في حالة توازن مستمر قبل أن ييسط سيطرته عليها، وبتطور الإنسان وازدياد السيطرة على البيئة بدأت مظاهر الحياة بالتدهور و الضمور، لأجل ذلك سنت القو انين من أجل حماية الثروة القومية والمحافظة عليها للإبقاء على التوازن البيئي وذلك من خلال الاهتمام بالمحميات الطبيعية. و عرفت بأنها عبارة عن مساحة كبيرة من الأراضي تخصص بو اسطة قانون لحماية المصادر الطبيعية التي تشمل المصادر الحيوية من مجتمعات نباتية وحيو انية وجميع أثكال الأرض وتضاريسها ومساقط المياه و الينابيع [28] وكذلك عرفت بأنها قطعة من الأرض ذات مساحة معينة تحدد بواسطة القانون من أجل حماية النباتات و الحيو انات البرية الأخرى وصون الحيوانات المهددة بالإنقراض و أنواع النباتات النادرة ذات الأهمية الاقتصادية ويمنع فيها ممارسة النشاطات التي تضر بمحتوياتها للحفاظ عليها من الاندثار وإبقائها بهيئة مو اقع طبيعية[31]، وكذللك تعرف بأنها مناطق محددة الأبعاد الجغر افية لها قو انين تعزز الموارد الطبيعية والمحافظة عليها و على ما تتميز به من التتوع البيئي . وكذللك تعرف بأنها عبارة عن مساحة من الأرض أو من المياة ( الساحلية أو الداخلية ) تتميز بوجود كائنات حية نباتية أو

حيو انية أو مميز ات طبيعية لحماية ثقافية أو عملية سياحية أو جمالية تحت الحماية القانونية لحماية ثروتها البيئية. [16] 


$$
\begin{aligned}
& \text { يشترط توفر واحد أو أكثر من المعوقات التالية في الموقع و عند اختبارة. } \\
& \text { 1 } \\
& \text { 2. وجود تثكيلات جيولوجيا متميزة . } \\
& \text { 3. أهية الكائنات التي تعيش فيها كمصادر ور اثية. } \\
& \text { 4. توفر العو امل التي تساعد المو اقع لكي تكون مختبراً للأبحاث البيئية والعلمية. } \\
& \text { 5. إكانية استغلال السياحي البيئي للمو اقع ( السياحة البيئية ). }
\end{aligned}
$$

6. إمكانية تقديم مصادر دخل للسكان المحليين من دون تعريض مكونات الموقع لخطر التدهور. [32]

\section{بعض الاعتبارات الهامة عند إقامة المحميات الطبيعية:}

1- يجب أن يعتمد برنامج تكوين أي محمية على سباسات وأهداف محددة يتبناها مؤسسات حكومية على أعلى المستويات وتتمثل في المحافظة على انتاجية الموارد وإعادة تكوين مخزونها والحفاظ على التباين في الموارد الطبيعية وحماية المواقع و الأهمية الجمالية و التاريخية و الثقافية و التعليمية و التنمية المستدامة. 2- تنكيل فريق لفرض عملية انتخاب واختيار و إقامة المحميات على أساس علمي. 3- إجراء مسح شامل لعناصر الييئة بالقدر المستطاع، للتعرف على المواقع التي تستحق لحماية وجمع وجمع المعلومات حولها، وتثمل الدسوحات توزيع ووفرة الأنواع في المواقع الطبيعية طبقاً لنظام معياري لتصنيفها وكذللك دراسة الخصائص الفيزيائية و الكيميائية و النماذج و الاستخدامات الاقتصادية و الاجتماعية و الإمكانيات السياحية و الترفيهية ـ [32]

\section{الغرض من تأسيس مناطق المحميات الطبيعية :}

إن العاملين في مجال الطبيعة يحاولون التقليل من الخسارة أو النقص في المصادر الحيوية وذلك للحفاظ على التباين الحيوي والذي يعتبر بقاؤه أساسياً لاستمر ار حصولنا على الفائدة من الأنو اع البرية وذلك يتمتل في الجو انب الرئيسية النالية : المحافظة على العمليات الإيكولوجية الأساسية التي ترتبط باستمر ار الحياة وبقاء الإنسان وتقدمه. 
1. المحافظة على الأنظمة البيئية الموجودة في البلاد والمناطق التي تضم أحياء مهددة بالانقر اض و المناطق المهمة بيئياً وذللك للمحافظة على التنوع الحيوي في البلاد ـ [28]

المحافظة على المناطق ذات طبيعة جمالية وتكوينات صخرية وطبيعية ذات جمال خاص وبذلك تمثل المحميات

الطبيعية أحد العناصر الأساسية لصيانة البيئة.

حماية الأنواع البرية المهددة بالانقراض و العمل على تكاثر ها في بيئة ملائمة بما يحقق صيانة التنوع الوراثي من خلال الحماية البيئية للأنواع المقيمة أو المهاجرة .

حماية وتأكيد استمرار استقلال الأنظمة التقليدية والتي يعتمد عليها ملايين البشر [37]، و إن العاملين في مجال حماية الطبيعة يحاولون التقليل من النقص للحفاظ على التوازن البيئي ولا نستطيع القول بأن جميع الأنواع تتساوى في فائدتها بل إن بعض الأنواع أكثر فائدة من الأخرى و هي تضم : [28] 1- أنواع النباتات البرية التي لها علاقة بالمحاصيل الغذائية للإنسان . 2- الحيو انات البرية التي لها صلة قرابة مع الحيوانات الداجنة. 3- الحيو انات القابلة للتنجين.

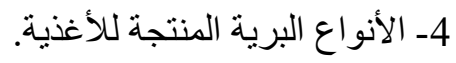
5- الأنواع التي يستغلها الإنسان للحصول على الأصباغ والأدوية .

فئة V المظهر الأرضي / البحري المحمي Protected Landscape / Seascape و هي منطقة محمية تدار بشكل أساسي لصيانة المظهر الأرضي والمظهر الأرضي والمظهر البحري والترفيه. ومن أجل تحديد الاختلافات في علم المصطلحات Terminology فإن الاتحاد الدولي لصيانة الطبيعة IUCN طوّر نظاماً لتصنيف المناطق المحمية أقيم على أهداف إدارية، وعليه فقد أدرجت سبع فئات، والفئات تضم تدرجاً من التدخل البشري يتدرج من عدم وجود تدخل فعال فإن فئة Ia ، Ib إلى مسنويات عالية نسبية من التنخل فإن فئة V جدول (1) وشكل (1) . وينبغي التأكيد هنا بأن كل الفئات متساوية في الأهمية ومناسبة لصيانة التنوع الحيوي ـ [15] فئة I محمية طبيعية كاملة / منطقة البرية Strict Nature Reserve / Wilderness Area وهي منطقة محمية تدار بشكل رئيسي لغرض علمي أو لحماية الحياة البرية . 


\section{فئة Ia محمية طبيعية كاملة}

منطقة محمية تدار بشكل رئيسي لغرض علمي، وهي منطقة من الأرض و / أو البحر تمنللك الملامح و / أو الأنواع

المذهلة ( الاستثنائية ) أو الممثلة للنظم البييئية، والجيولوجية، والفيزيولوجية المتوفرة بشكل رئيسي للبحث العلمي و / أو المر اقبة البيئية .

\section{فئة Ib - المنطقة البرية:}

منطقة محمية تدار بشكل رئيسي لحماية الحياة البرية، وهي منطقة برية و / أو بحرية غير معدلة Unmodified أو

معدلة بشكل بسيط Slightly تكمن أهميتها بخاصيتها الطبيعية ولا يوجد فيها استيطان دائم أو هام، و التي تتم حمايتها و إدارنها لكي تحتفظ بوضعها الطبيعي .

\section{فئة II الحدائق ( المنتزهات ) الوطنية National Park}

منطقة تدار بشكل أساسي لحماية النظام البيئي والترفيه: وهي منطقة طبيعية من الأرض و / أو البحر، مصممة من

$$
\text { أجل[16،ص[30]: }
$$

أ. حماية التكامل الأيكولوجي لواحد أو أكثر من النظم البيئية للأجيال الحالية والمستقبلية. ب. استثناء الاستغلال الضار بالأغر اض التي صممت من أجلها المنطقة. ج. توفير أساس من أجل الفرص الروحية و العلمية والتربوية و الترفيه، وكل منها يجب أن يكون منسماً بيئياً وثقافياً وحضارياً.

\section{فئة III المعلم الطبيعي Natural Monument}

$$
\text { منطقة محمية تدار بشكل أساسي من أجل صيانة ملامح طبيعية معينة . }
$$

و هي منطقة تحتوي على معلم أو أكثر من معلم طبيعي أو حضاري معين الذي يكون مذذهلاً أو متفرداً بسبب ندرته أو جماليته

$$
\text { أو أهميته الحضارية . }
$$

\section{Habitat Species Management Area منطقة إدارية الموطن / الأنواع IV فئة}

$$
\text { منطقة محمية تدار بشكل أساسي من أجل الصيانة عبر التدخل الإداري . }
$$

و هي منطقة من الأرض و / أو البحر تتعرض لتنخل نشط من أجل إدارنها بحيث تؤمن حماية مواطن الحيوانات و / أو النباتات و / أو لمواجهة منطلبات أنواع معينة منها. و هي منطقة من الأرض، مع شاطئ وبحر ملائم، حيث إن التفاعل بين الإنسان و الطبيعة عبر الزمن قد انتج منطقة ذات خاصية مميزة تحتوي على قيمة هامة جمالية وأيكولوجية و / أو ثقافية ، غالباً ماتكون ذات تنوع حيوي عالي، وتعتبر حماية سلامة هذا التفاعل التقليدي أساسية من أجل حماية وإدارة وتطور مثل هذه المنطقة . 


\section{: Managed Resource Protected Area محمية إدارة الموارد VI فئة}

منطقة محمية تدار بشكل أساسي من أجل الاستعمال المستدام للنظم البيئية الطبيعية. وهي منطقة تحتوي على نظم بيئية غير معدلة بشكل واضح، تدار بشكل أساسي لضمان حماية وحفظ طويل الأمد للتنوع الحيوي، وفي الوقت نفسه توفر تدفقاً مستداماً للمنتجات و الخدمات الطبيعية لإشباع حاجات المجتمع المحلي ـ [18] جدول (1): مصفوفة أهداف إدارة المناطق المحمية حسب فئات الإتحاد الدولي لصيانة الطبيعية

\begin{tabular}{|c|c|c|c|c|c|c|c|}
\hline $\mathrm{VI}$ & $\mathrm{V}$ & IV & III & II & $\mathrm{Ib}$ & $\mathrm{Ia}$ & أهداف الإدارة \\
\hline 3 & 2 & & 2 & 2 & 3 & 1 & البحث العلمي \\
\hline 2 & - & 3 & 3 & 2 & 1 & 2 & حماية البرية \\
\hline 1 & 2 & 1 & 1 & 1 & 2 & 1 & التنوع الجيني / الأنواع \\
\hline 1 & 2 & 1 & - & 1 & 1 & 2 & الخدمات البيئية \\
\hline 3 & 1 & 3 & 1 & 2 & - & - & الملامح الطبيعية / الثقافية \\
\hline 3 & 1 & 3 & 1 & 1 & 2 & - & 2 السياحة و الترفيه \\
\hline 3 & 2 & 2 & 2 & 2 & - & - & التربية؛ \\
\hline 1 & 2 & 2 & - & 3 & 3 & - & الاستعمال المستدام \\
\hline 2 & 1 & - & - & - & - & - & الخصائص الحضارية \\
\hline
\end{tabular}

مفتاح : 1= هدف أولي ، 2= هدف ثانوي ، 3= من المحتمل غير قابل للتطبيق ، ـ = غير قابل للتطبيق .

طبيعي

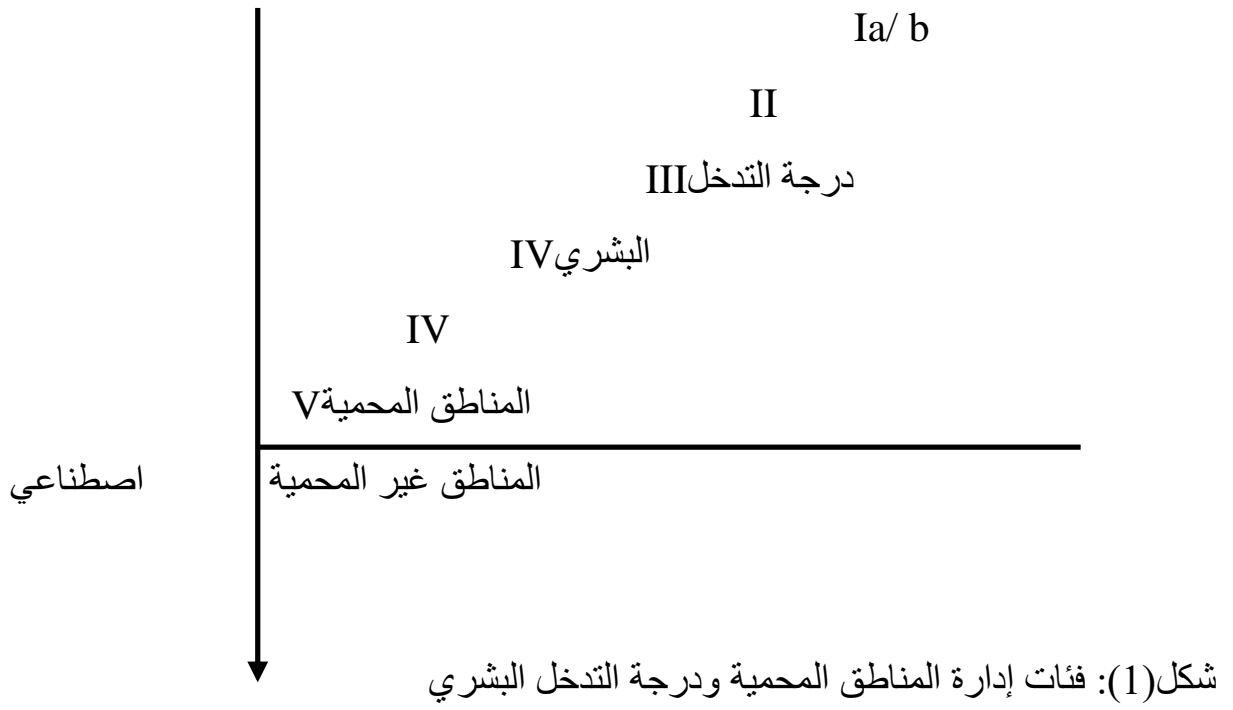




\section{دور المحميات الطبيعية في التنمية المستديمة :}

\section{تساهم المحميات الطبيعية في التنمية المستدامة بالطرق التالية : [7]}

1. المحافظة على استقرار البيئة التي تمثلها هذه المناطق وتقلل تبعاً لذلك من الفيضانات أو الجفاف وتحمي التربة من

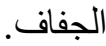

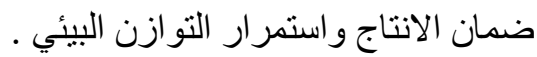

$$
\begin{aligned}
& \text { توفير الفرصة للبحث العلمي ومتابعة الأحياء البرية والنظم البيئية ودر اسة وفهم العلاقات مع تتمية الإنسان. } \\
& \text { توفير الفرصة لإحداث واستمر ار التنمية في المناطق النائية والاستغلال الأمثل للأر اضي الهامشية. } \\
& \text { استغلال الفرصة للتوعية البيئية . } \\
& \text { تسهيل التنزة و الاستجمام والاقتر اب من عالم الطبيعة. } \\
& \text { تكمن أهمية المحميات الطبيعية في الجو انب الآتية : }
\end{aligned}
$$

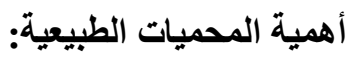

1. الجانب السياحي والترفيهي: تتمتع مناطق المحميات الطبيعية بقيم جمالية مختلفة فالبعض منها يقع في مناطق تتوفر [31] فيها المياه والخضرة وأخرى تتميز بالتنوع الحيوي مثل الطيور و الأسماك والجزر الخضر اء العائمة فوق الماء الجانب العلمي:إن المحمية الطبيعية تتضمن مفردات متنوعة تمكن الدارسين والباحثين من إجراء دراسات ذات جو انب مختلفة لتطوير المواد الطبيعية ( النباتية والحيو انية ). [28]

الجانب الاقتصادي: إن إنشاء وتطوير واستثمار المحميات يعد الدافع الكبير لتطوير ما تحويه من موارد اقتصادية كالقصب و البردي والصناعات المحلية والعمل على توفير فرص عدة لتكاثر الحيوانات وخلق فائض في أعدادها. الجانب التراثي: تمثل المحميات بيئات متنوعة لها مكانتها في حياة ساكنيها، إذ تعد موطن أسلافهم وفيها مصادر حياتهم ولا سيما وإن المحمية تمثل معرضاً بيئياً يدعو إلى غرس القيم والعادات التي تمسك بها سكانها عبر الزمن 


\section{المحميات الطبيعية ودورها في السياحة البيئية}

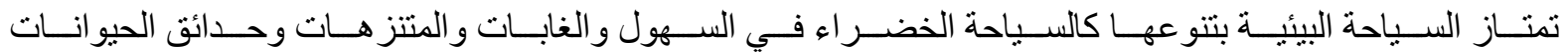

وسـياحة المحميـات الطبيعيـة و التـي يطلـق عليهـا السـياحة الفطريـة وسـياحة صـيد الحيو انـات البريـة و الطيـور و الأسـماك

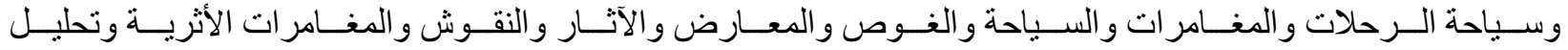

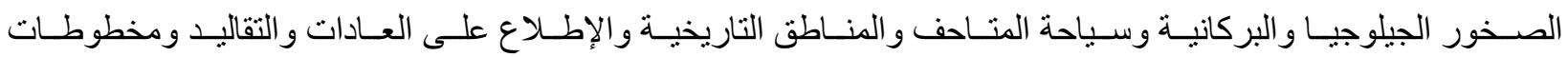
التر اث و المعارف و العلوم و الثقافة السياحية والثقافية وتثنمل سياحتي الآثار و التاريخ. [13]

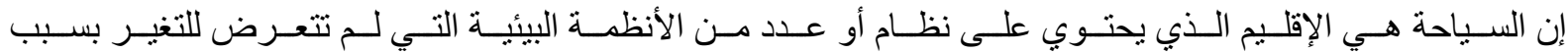

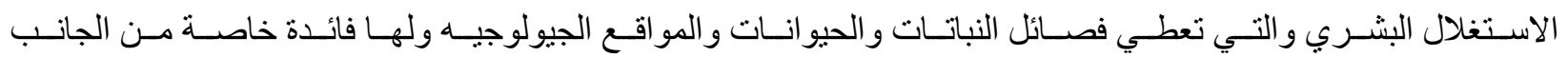
التربوي و العلمي و الترفيهي وتوجد فيها مناظر ذات قيمة جمالية كبيرة. [35]

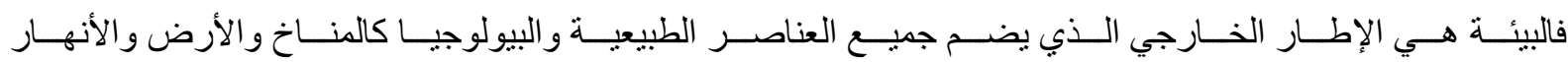
و البحيـر ات والجبـال و التي يعبيش فيهـا الإنسـان مـع الكائنـات الأخرى مـن نباتـات وطيور وحيوانـات في تكامسل وتجـانس

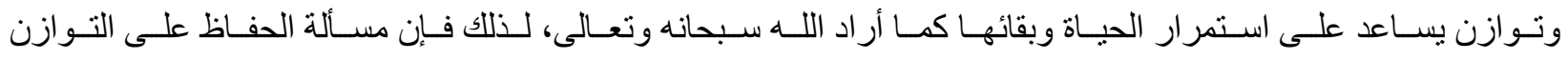

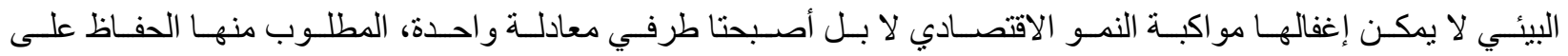
التكـافؤ فيهـا لضـمان ديمو مــة الحيـاة واسـتمر ار ها و أكـد برنـامج الأمـم المتحـدة للبيئة عـن وجـود حاجـة ضـرورية لإنعـاش النمو بعد أن أفادت التقارير الواردة من دول عديدة تصف الأوضاع البيئية وأحوال المعيشة فيها بالتدهور. [5]

\section{أنماط وأشكال الحركة السياحية:}

اعتمـدت العديـد مـن المصـادر التـي ركزت على موضـوع أنـواع وأثـكال الحركـة السـياحية على عـد مـن المعـايير التـي تـتم بموجبهـا تصـنيف السـياحة إلـى أنمـاط مختلفـة يصـعب فصـل بعضـهـا عن البعض الآخـر حيـث يلاحظ القـارئ تـداخلاً بين عـد غير قليـل مـن هذه الأنمـاط وتأخذ السـياحة أنو اعـاً متعـدة اعتمـاداً على الهدف أو الغايـة مـن قيـام السياحة وهي تقسم إلى أنواع : السـياحة الثقافيـة: نسـتدل مـن الحديث النبـوي الثـريف ( اطلبـوا العلـم ولـو كـان في الصـين ) على أن السياحة الثقافيـة لهـا

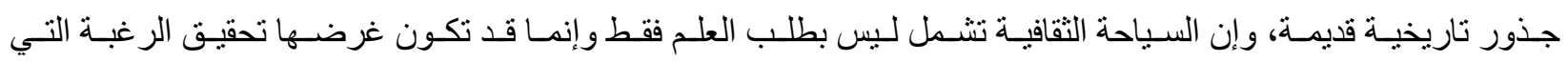


يسـعى الإنســان إلـى تحقيقهـا و المتمثلــة بـالإطلاع وزيـادة المعرفـة بطبيعـة الثـعوب و عـاداتهم وتقاليـدهم و علـى الآتـار و المنجزات التي حققتها الحضارة . [10]

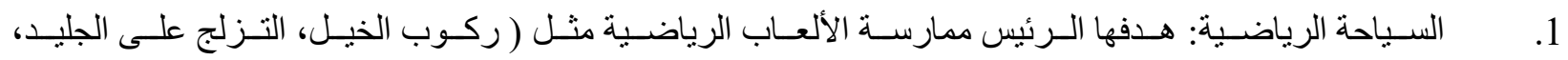

$$
\text { الزوارق الثراعية و الصبد ). }
$$

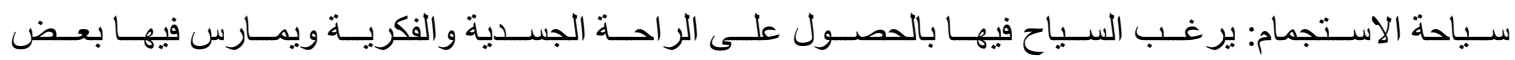

[4] [4] النشاطات الملائمة .

السـياحة طلبـا للاستشـفاء و العـلاج و النقاهـة: لابــــــن التفريـق بـين هـــه المصـطلحات الثلاثـة، فالاستشـفاء هـو

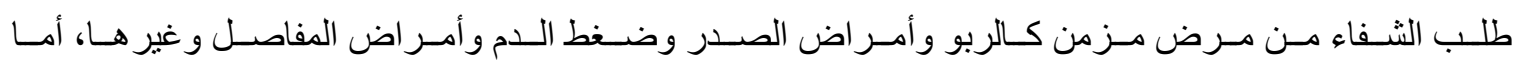
العلاج فهو طلب علاج من مرض خطير خارج مكان الإقامة .

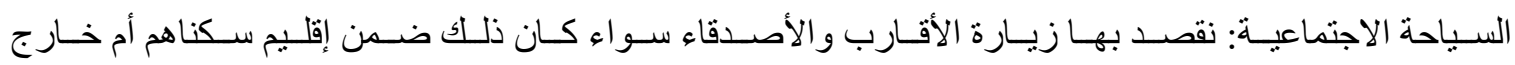

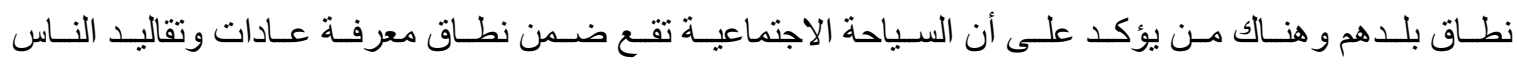
والتعرف على حياتهم. [23]

\section{مستقبل السياحة البيئية:}

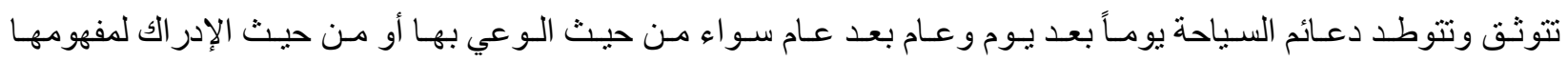

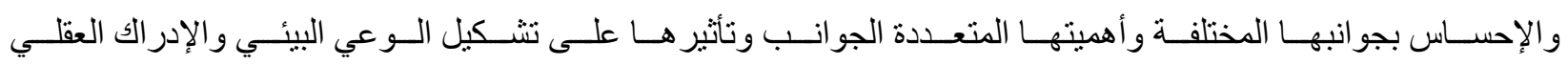
بقضـاياها المتجـددة ومـــا تتطلبـة هـذه المسـتجدات مـن تحفيـز للوجـدان وشـحذ العاطفـة بتأييـدها ودعمهـا. وتـزداد روابـط السياحة البيئية حتى أصبح هناك تكامل بين السياحة البيئية وباقي الأنشطة التي رسمها الإنسان بصفة عامة.

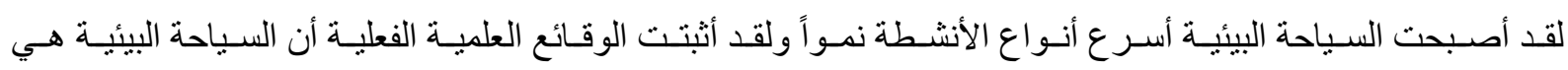
السياحة المنلى لتنمية المناطق السياحية ومن خلال ذلك تؤثر السياحة البيئية في كافة مجالات الحياة .

بـدا الا هتمـام بدر اسـات المسـتقبل فـي العمـل السـياحي بصـفة عامـة وبالسـياحة البيأيـة بصـفة خاصـة مـن خـلال الخـوف على نضوب الموارد ومن خلال دراسة الخطر و التهديد الذي يمثلة التلوث البيئي للحياة في كواكب الأرض ـ [15]

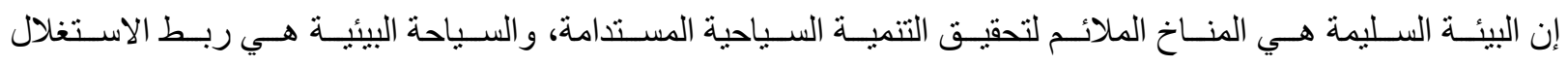

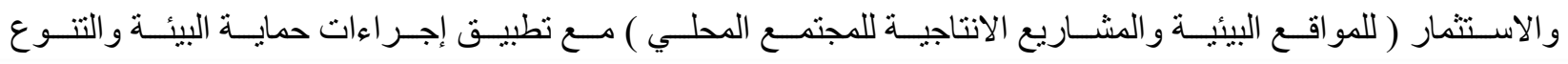




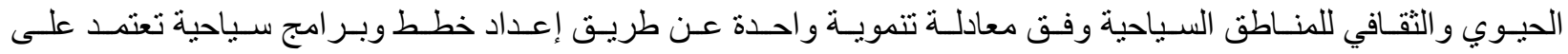

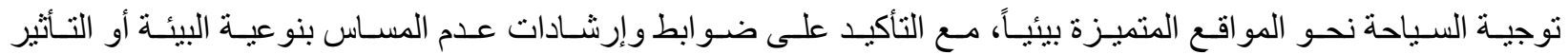

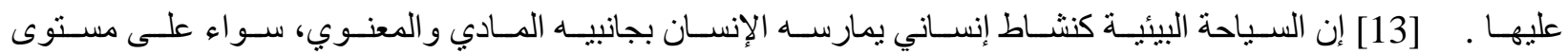

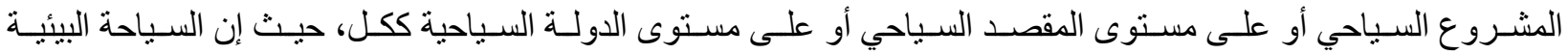

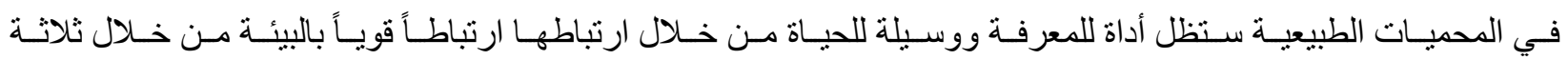
جو انب وهي : [15]

2.

المبحث الثاني : التوزيع الجغرافي للمحميات في العالم مع إشارة خاصة للعراق:

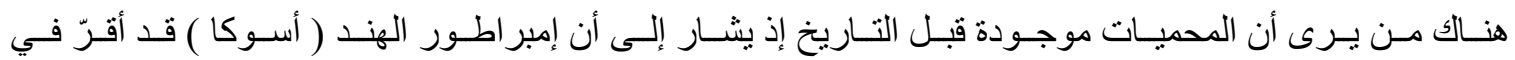

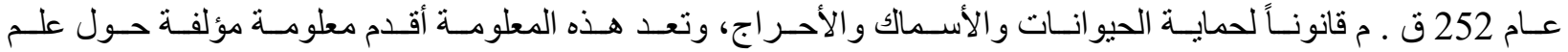
يهـدف إلـى حمايـة الطبيعـة وإيجـاد المنـاطق المحميـة ولكن مـن قبـل هـذا التـاريخ كانــت المنـاطق المحميـة تقـام لأسـباب

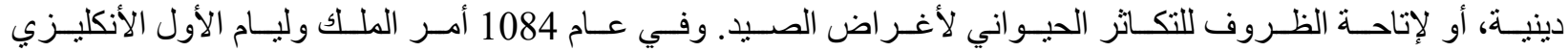

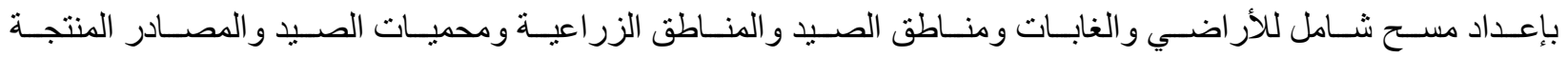
للملكة لوضع خطة مناسبة للتنمية والإدارة. اهتمـت دول عديـدة مـن العـالم بالمحميـات ووصـل عـدد المحميـات إلـى أكثر مـن (1100) محميـة في أكثر مـن 100 دولــة، وأثــهر هـذه المحميـات هـي محميـات كينيـا. بـــخ مجمـوع مسـاحات المحميـات في العـالم أكثـر مـن (

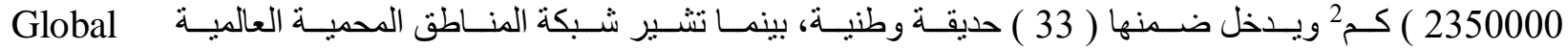
13232275 إلى وجـود حـوالي (30530) منطقة محميـة تمتـد فوق مسـاحة تبــغ ) كـ²، تمثنل 8.83 \% مـن مسـاحة الأرض، وهـذه النسـبة يمكن أن تـزداد بمعدل 1\% أو أكثر بسـبب العـد الكبيـر مـن المحميات البحرية أو مناطق محمية تمنلك مكون بحري . 


$$
\text { جدول(2): التوزيع الجغر افي للمحميات و إعدادها في العالم }
$$

\begin{tabular}{|c|c|c|c|c|c|}
\hline |مساحة|لمحميات كم2 & |عدد المحميات & كال|الإقليم & كم2 مساحة المحه & |عدد المحميات & لإقليم \\
\hline 883.681 & 1078 & ثرق آسيا & 3.788 & 99 & اركتيكا \\
\hline 4.083 .806 & 6711 & أمريكا الثمالية & 603.601 & 9.325 & يوبا \\
\hline 1.838 .826 & 1.437 & |أمريكا الجنوبية & 13.113 & 152 & سفيك \\
\hline 657.935 & 648 & |ثمال أور اسبا & 108.637 & 579 & ل اريبي \\
\hline 1.318 .615 & 927 & | أفريقيا & 1.109 .024 & 5.882 & راليا ونيوزيلندا \\
\hline 1.037 .576 & 542 & |الأوسطال إفريقيا والثرق & 86.049 & 384 & يكا الوسطى \\
\hline 755.836 & 343 & | إلغريقيات $\quad$ الوسطى & 212.924 & 719 & ي ب أسيا \\
\hline 13232275 & 30350 & |المجموع & 518.864 & 1.524 & وب شرق آسيا \\
\hline
\end{tabular}

المصدر: [8]

وفي الوطن العربي تبلغ مساحة المحميات نحو (350320) كم²مشكلة نحو (3.74) \% من إجمالي مساحة الوطن العربي، ويختلف توزيع المناطق المحمية بين المناطق الجغرافية بالوطن العربي، فالجزيرة العربية تمنلك (44.4 )\% من المساحات المحمية، والمنطقة الوسطى ( مصر و السودان و الصومال وجييوتي ) (28.3) \% ، ودول المغرب العربي في الثمال الإفريقي [8)

\section{المحميات الطبيعية في العراق:}

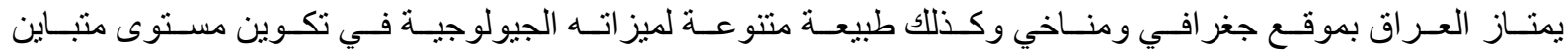

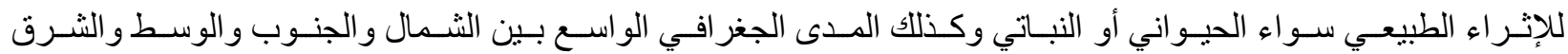

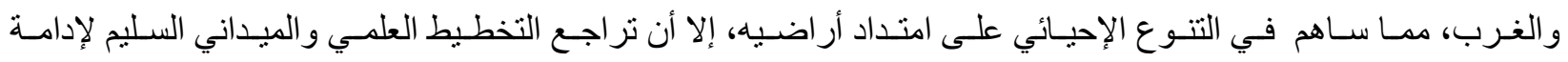

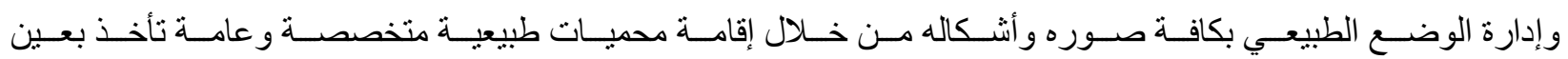

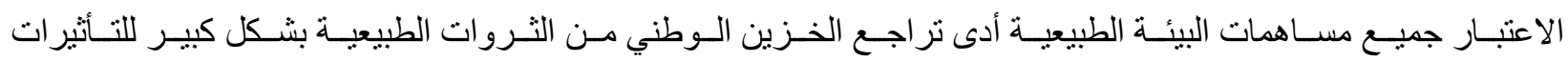
[25] [25 [المناخية و البشرية لقـد عانـت المحميـات الطبيعيـة مـن حـالات السـلب و النهب والعبـث الغير مسؤول مـن قبـل كثير مـن الــخلاء، ممـا تسبب فـي انقـر اض الكثبـر مـن الأحيـاء النباتيــة و الحيوانيـة، و علـى الـر غم مـن أن حالــة انقـر اض الحيو انـات هـي حالــة طبيعيـة إلا أنها تحـدث بسـرعة كبيـرة جـاً، وفي تقريـر للـدكتور حسين العلـي مـدير متحف التـاريخ الطبيعسي في العـراق، تعتبر

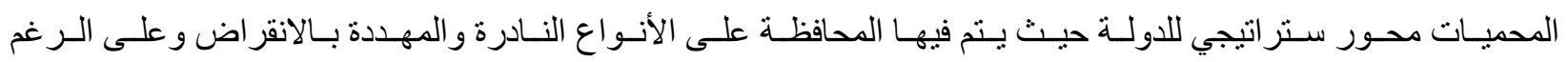




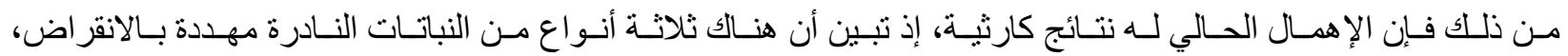
ومن الثذييات منها تسعة مهددة بالانقر اض كما أن هناك ( 17 ) نوع من الطيور مهدد بالانقر اض . [33] لـذلك يعـد تأسيس و إنثـاء المحميـات الطبيعيـة و إدارتهـا مـن أهـم وسـائل الحفـاظ على التتـوع الأحيـائي وكذللك الحفـاظ على الأنواع النادرة من التهديدات ومن خطر الإنقر اض والحرص على استدامتها.

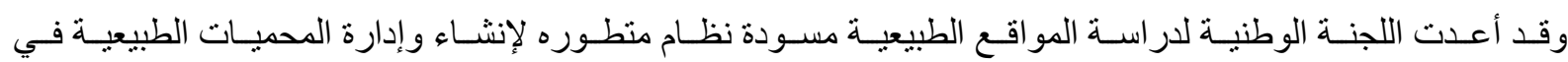
العر اق و الذي تم مر اجعته في مجلس شورة الدولة . [2] المحميات الطبيعية واستثمار ها سياحياً في العر اق: إن المنـاطق الحياتيـة فـي العـراق التـي يتحـدد بهـا نـوع معين مـن الحيو انـات، غيـر منفـق عليهـا بشـكل نهـائي حتى الآن،

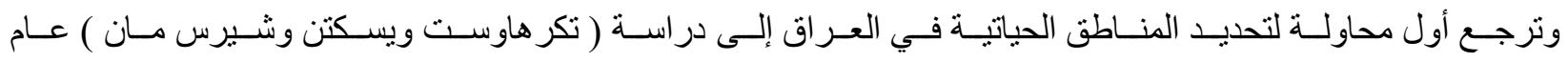

و أدناه المناطق الحياتية البرية للعر اق وحسب ما أورده ( العالم هالت ). [29]

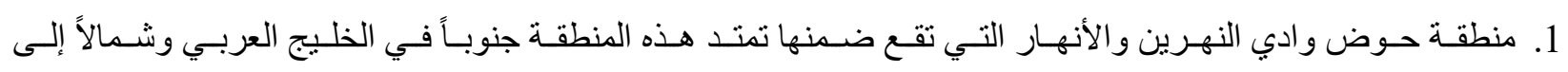
مدينـة هيـت على نهـر الفـرات و إلى سـامر اء على نهـر دجلـة ثـم جنوبـاً إلى الأهوار، ويعـيش فيهـا الكثيـر مـن الطيـور وكلب الماء الثمين الفراء وابن أوى. 2. - منطقة الصحر اء الجنوبية الغربية:

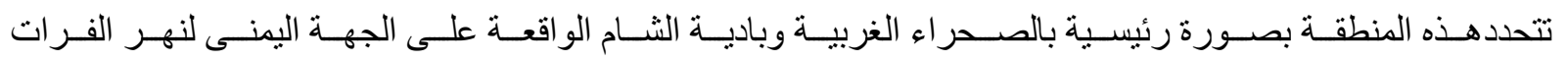

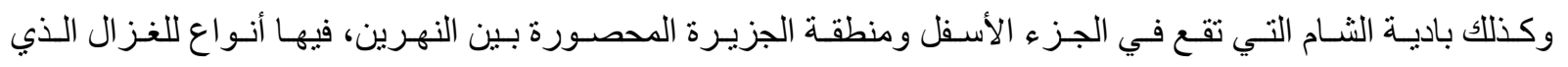
وصل درجة الندرة و انقرض منها الفهد المرقط والوشق أما الثعلب و الذئب فوجد بإعداد قليلة. 3. منطقة السهول وسفوح الجبال: وتثـــل هـذه المنطقـة أر اضــي مرتفعـة متموجـة ذات تربـة صـخرية ناعمـة وأر اضـي زر اعيـة وتـلال صـخرية وتضـم هـهـ المنطقـة أغلب أجـز اء الجزيـرة وكـللك الأر اضــي الو اقعـة بـين نهـر دجلــة والمنطقـة الجبليـة ويعيش فيهـا الـدراج و الطيور الخو اضة، أما السهول الثمالية فيعيش فيها القط البري و الوشق و الحجل سوسك. 


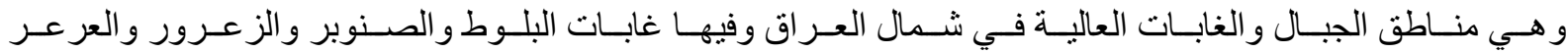

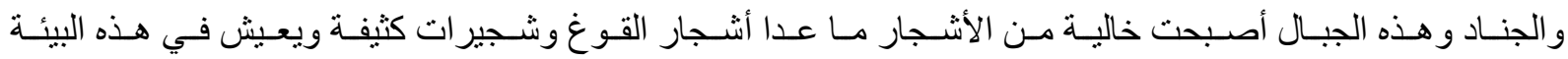

$$
\begin{aligned}
& \text { النمر المرقط والماعز الجبلي إضافة إلى قوارض وآكلات الحشرات. } \\
& \text { 5. منطقة المستنقعات و الأهوار الجنوبية وسواحل الخليج العربي: }
\end{aligned}
$$

وتتـــل هـذه المنـاطق الأهـوار الجنوبيـة في العمـارة والناصـرية والبصـرة وسـواحل الخــيج العربـي، ويعـيش فيهـا

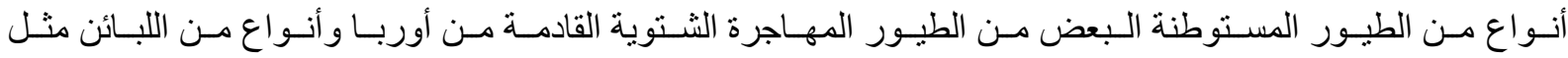

$$
\text { الخنزير، و الذئاب و الثعالب و الأر انب . }
$$

\section{المحميات الطبيعية المقترح إنشائها في العراق : [29]}

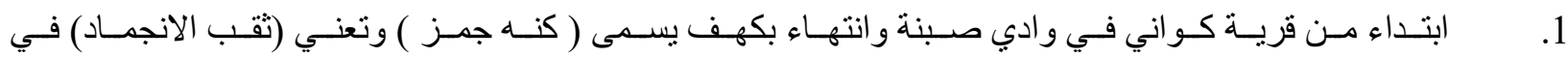

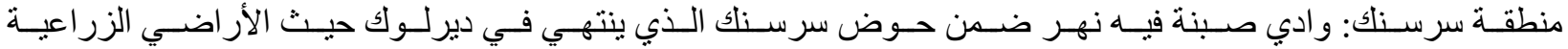

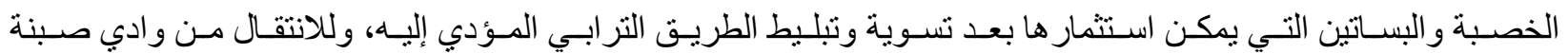

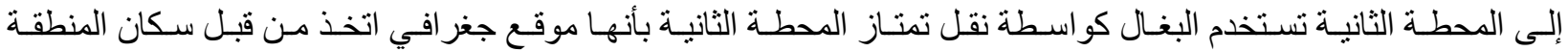
كزار حيث يعتقد أنه يشفي الأمر اض الجلدية. ب- جزيرة ( جديدة الشط ) في وسط نهر دجلة:

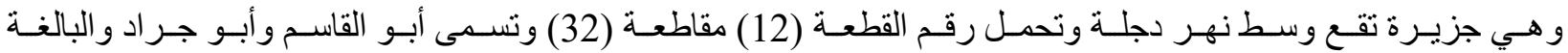
مساحتها (414) دونم. تـ المنطقة الصحر اوية في كربلاء:

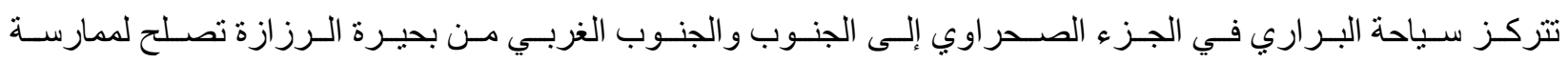

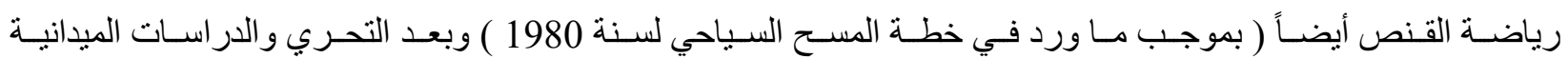
وجد أن مناطق الصيد والحياة البرية تتوزع على منطقتين رئيسيتين :

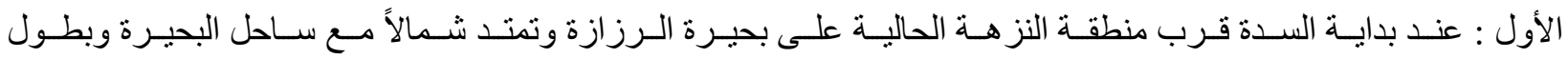

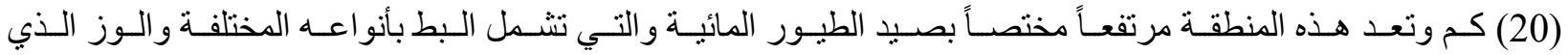
يخرج من اليابسة باتجاة المياه في فترات من النهار في مو اسم معينة و لا سيما ما بين شهري تشرين الأول ونيسان. الثانية : تقع ضمن الرقعة الجغر افية لناحية النخيب شمال وجنوب طريق الحج البري . 
ويعـود سـبب اختيـار هـذه المو اقـع لإنشــاء المحميـات إلى تعـد البيئـات و التكوينـات و المـوارد الطبيعيـة مـن وديـان وسـهول

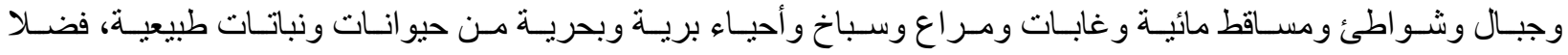
عن احتو ائها على كثير من المعالم الأثرية والتاريخية والسياحية البارزة . وعليه فقد تم تحديد الفو ائد الاقتصادية من إنشاء المحميات الطبيعية بالآتي: 1- تـوفير مـردود مـالي للاولـة نـاتج مـن السياحة البيئيـة حيث تسـتقطب أكبر عدد مـن السياح الأجانـب لتنو عهـا الأحيائي وجمال بيئتها.

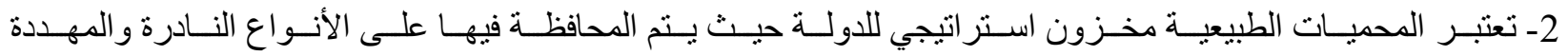
بالانقر اض و التوازن البيئي الطبيعي. 3- تعتبر مختبر اً طبيعياً لطلاب الدر اسات و البحوث التطبيقية و المعاهد ومؤسسات البحث العلمي ـ. 4- تساعد المحميات الطبيعية على منع مخاطر التصحر للتربة. 5ـ تعزز التنمية المستدامة للأجيال القادمة.

\section{المبحث الثالث : المحميات الطبيعية في محافظة كربلاء} الجو انب التاريخية و الجغر افية لمنطقة الدر اسة:

$$
\text { أولاً : الموقع: }
$$

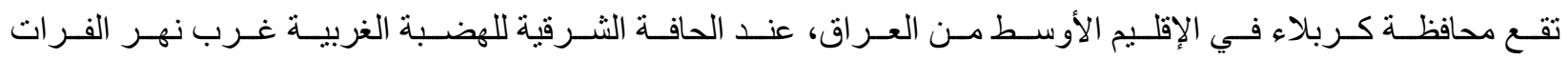

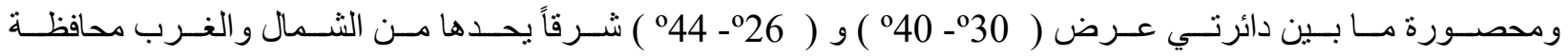

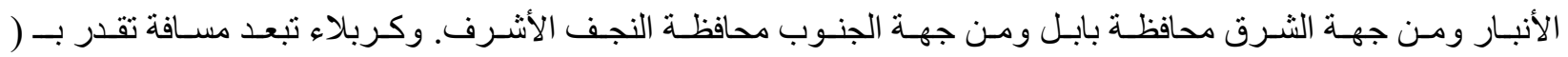
104 ) كـم جنـوب بغـداد، ينظـر خريطـة (1 )، وفـي غربهـا الصـحر اء الغربيـة التـي تضــ بحيـرة الـرزازة ومدينـة عـين التمـر ( شـثاثاً ) وحصـن الأخيضــر التـاريخي وكهـوف الطـار، وتمتــاز كـربلاء بموقـع جغر افـي وبيئسي ممتـــاز أكسـبها

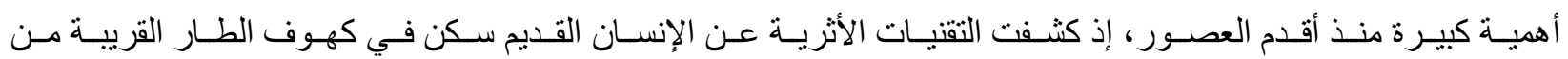

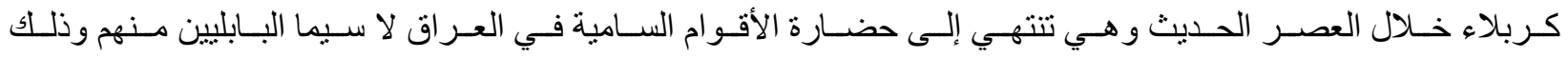

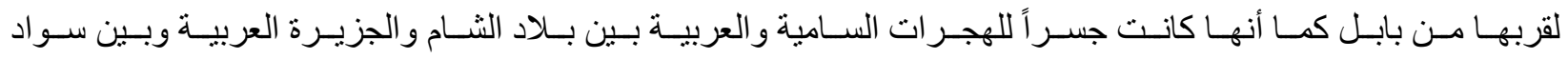


العـر اق. ويتضـح ممـا تقدم أن تـاريخ كربلاء موغـل في القدم و أنهـا كانـت مـن أمهات مدن طسـوج النهرين الواقعـة على ضـفاف نهـر بالاكوبـاس ( الفرات القديم ) و على أرضـهـا معبد للصـلاة كمـا يستـل على قدمها مـن الأسـماء التـي عرفت بها قديماً ك ( عمور ا، وماريا، وصفور ).

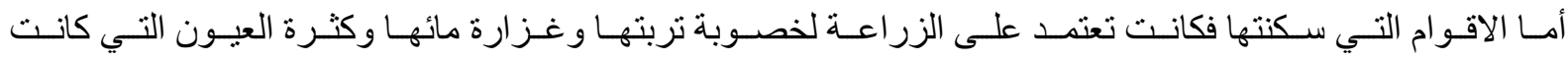
منتشـرة فـي أرجائهـا، ويـرى فريـق مـن المـؤرخين و اللغـويين ومـهم الأب انتـاس مـاري كرملـي أن لفظ كـربلاء ذكـر في كتب البـاحثين و منحسوت مـن كلمتين آثـورينتين همـا ( كرب ) بمعنى معبد أو حـرم و الكلمـة الثانيـة ( ال ) بمعنى إلـه في اللغة الآرامبة وتعني (معبد الآله ). [23]

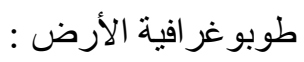

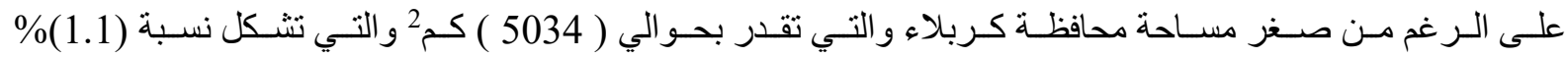
مـن مســاحة العـر اق الكليـة إلا أن ســحح المحافظــة عبـارة عـن هضـبة واسـعة ومتموجـة وأر اضـي صـحر اوية خاليــة

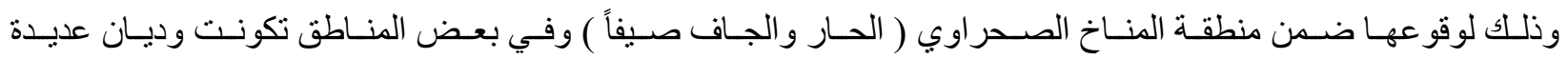
لا بفعل السيول المتكونة من مياة الأمطار و التي تسقط في فصل الشتاء بصورة دائمة وبفترات منباعدة ـ [15]

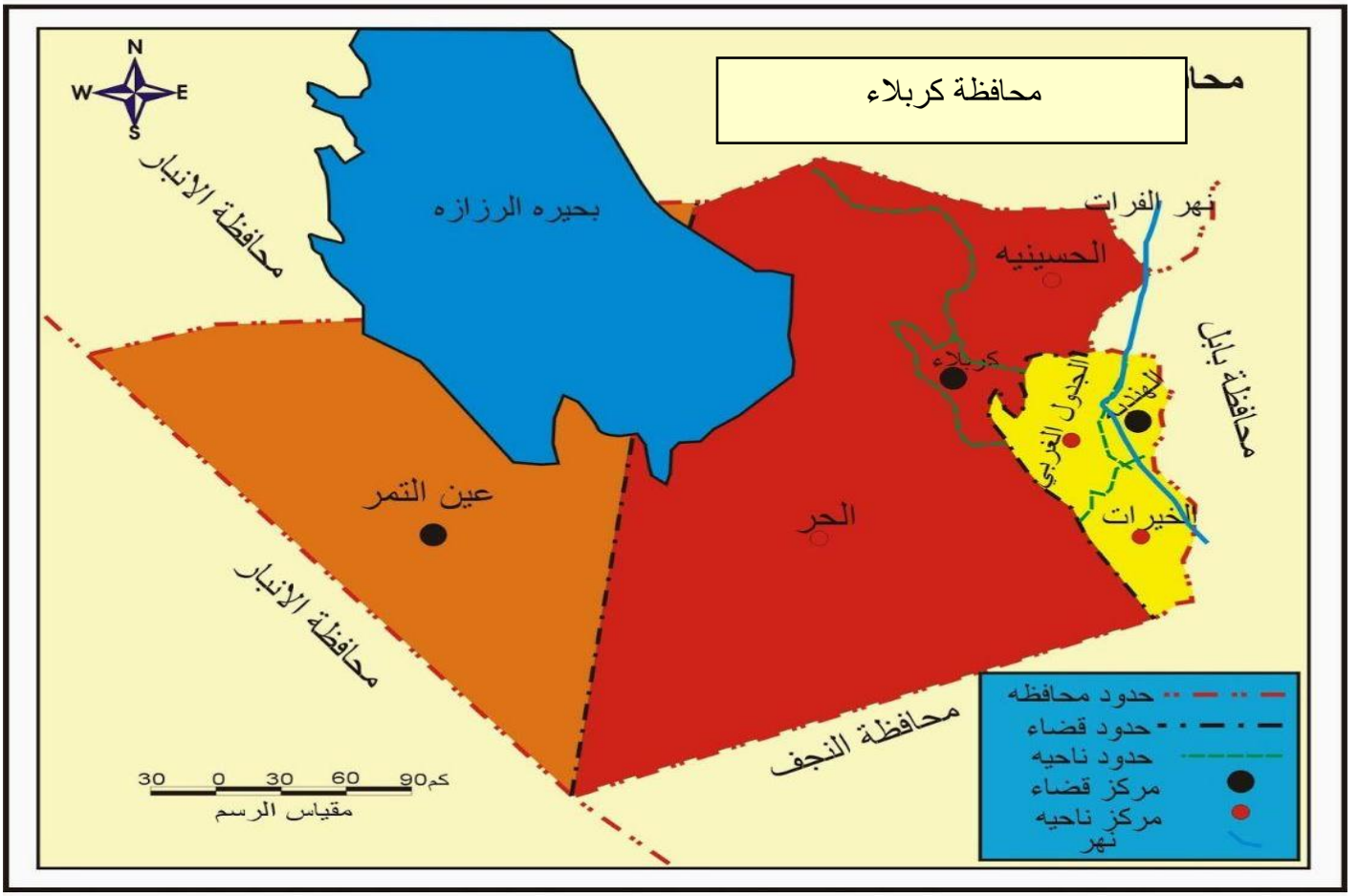

$$
\text { شكل(2): محافظة كربلاء الأدارية }
$$

المصدر :من عمل الباحثة اعنمادا على وزارة البلديات والأشغال 'قسم الوحدات الإدارية، خريطة محافظة كربلاء 2018 . 


\section{الظروف المناخية:}

إن من أهم العناصر التي تشترك في صياغة الواقع الخدمي لمركز أية مدينة هو مناخها ومنها ـ [30]

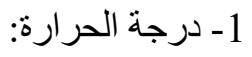

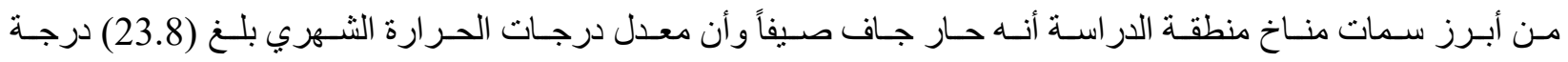

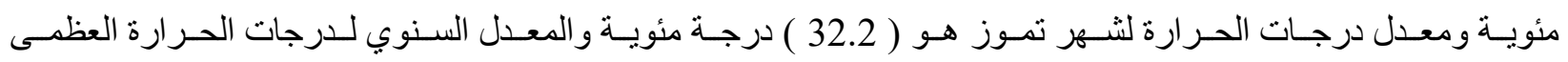

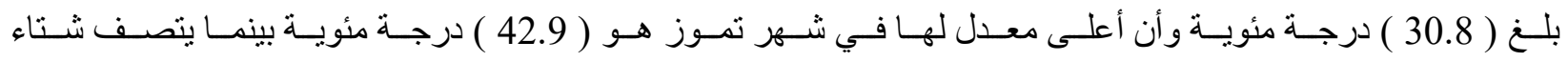

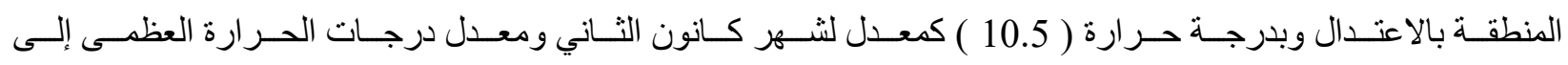
(17.0) درجة مئوية ومعدل درجات الحرارة الصغرى إلى ( 4.1 ) درجة مئوية.

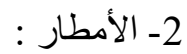

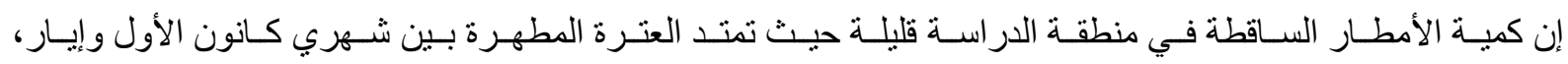
وأن أعلى كمية من الأمطار سقطت في شهر كانون الثاني ( 31.4 ) ملم.

أمـا الرطوبـة النسبية فتتبـاين بـين الثـتاء و الصـيف حيث يبلـغ أعلى معدل لهـا في شـهر كـانون الثـاني بنسبة ( 70\% ) و أقل معدل في شهر تموز بنسبة ( 28\% ) . : 3- الرياح

إن الريـاح السـائدة فـي المحافظـة هـي الريـاح الثـمالية الغربيـة في فصـل الصـيف، وتمتــاز هـذه الريــاح بارتفــاع درجـة

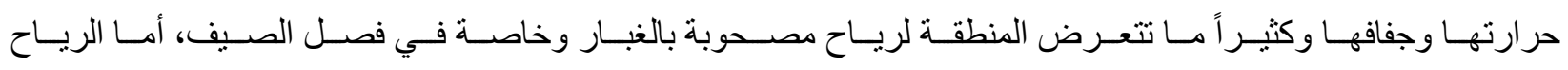
الشمالية الثرقية التي تهب في فصل الثتاء فيصحبها انخفاض شديد في درجات الحرارة .

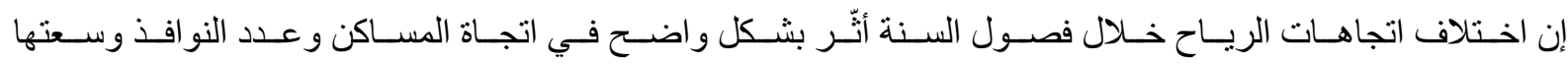
ومو اقع غرف العائلة. [23]

\section{واقع حال الإمكانيات السياحية لمنطقة الدراسة:}

ينمتـع أقليم كـربلاء بوجـود عـد مـن الإمكانيـات السـياحية التي سـاعدت بعضـها على قيـام النشـاط السـياحي في هـذا الإقليم على الرغم من ذللك نجد أن العديد من هذه الإمكانيات السياحية لن تستغل بعد ويمكن تقسيمها إلى : 


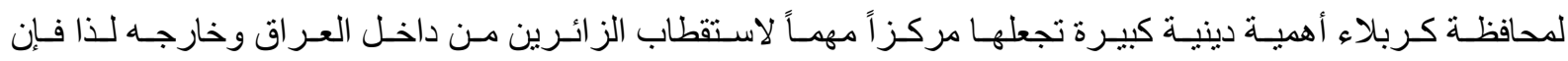

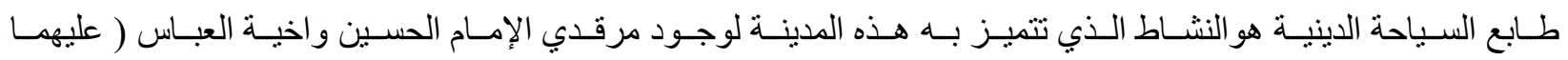
السلام ) إضافة إلى وجود عدد من المر اقد الأولياء الصالحين ( عليهم السلام ). 2- 2 - 2 الإمكانيات الطبيعية:

وتشــل بحيـرة الـرزازة ونهـر الفـرات فـي قضــاء الهنديـة ونهـر الحسـينية فضـلاً عـن البسـاتين الجميلـة وعيـون الميـاة في قضاء عين التمر.

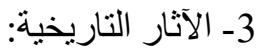

تشــل حصـن الأخيضـر و عـددا مـن القصــور التاريخيـة فـي عـين التمـر مثـل قصـر شـمعون وغيرهـا [3]، ينظرخريطة (2). توزيع المحميات الطبيعية في محافظة كربلاء : 1- بحيـرة الـرزازة:- تقـع بحيـرة الـرزازة على بعـــ (15) كـم إلـى الغـرب مـن مركـز مدينـة كـربلاء إلى الجنـوب مـن بحيـرة الحبانيـة وضــن الحـدود الإداريـة لمحافظـة كـربلاء و هـي على الحافـة الثــرقية للهضــة الصــحر اوية مـن العـراق و إلى الجنوب من بغداد و على بعد ( 102) كم² [ [36 ]

تتزود بحيـرة الـرزازة بالميـاة مـن بحيـرة الحبانيـة عـن طريـق جـول المجـرة الـذي يـربط البحيـرتين معـاً وييلـغ طولـة (12] كم² وذللك لتفريغ كميات المياة الفائضة التي تزيد عن الطاقة الاستيعابية لبحيرة الحبانية ـ كانــت بحيـرة الـرزازة تعـرف بهـور أبـي دبـس و هـو مـنخفض قديم التكـوين نشـاهد فيـه بقايـا المخلفـات الفراتيـة في العصـور القديمـة فقد كانـت قبـل اسـتكمال مشـروع الحبانيـة منخفضـاً طبيعيـاً تتخلـه السـيول والأمطـار تتجمـع في وحـنتين [3] [نفصلتين أحدهما في الجهة الغربية وتعرف ببحر الملح، والثانية في الجنوب الثرقي وتعرف بهور أبي دبس تبلـغ أدنـى نقطـة لمسـتوى الميـاة ( +17 ) م فوق مسـتوى سـطح البحر و أعلى مسـتوى للميـاة في البحيـرة عند حسالات الـذروة و الفيضــان ( +43 ) م فـوق مسـتوى سـطح البحـر، قابليـة الخـزن عنـــ مسـتوى ( +18 ) فـوق مسـتوى سـطح

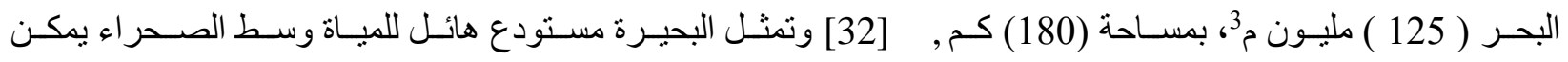




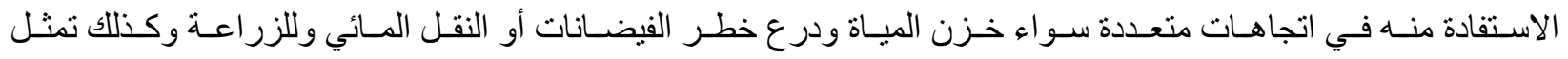
عنصـر أو حيـز تـوازن بيئـي متمبـز في إقليم المنـاخ الصـحر اوي السـائد في هذا الجزءء مـن العـراق ممـا يؤدي إلى إسـهام البحيـرة فـي تلطيـف الجـو (الطقس ) في مدينـة كـربلاء لــللك فـإن البحيـرة تمثـل إمكانيـة سـياحية راقيـة حـال اسـتثمار ها

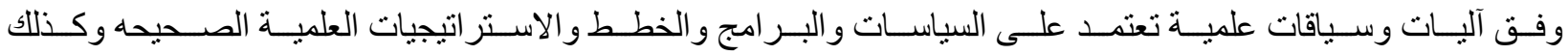
تبرزفيهـا أهميـة صــناعية مـن ناحيـة رمالهـا وأحجار هـا و أملاحهـا إذ يثـكل التكـوين الأيـوني لمياههـا نو عـا مـن الإمكانيـة

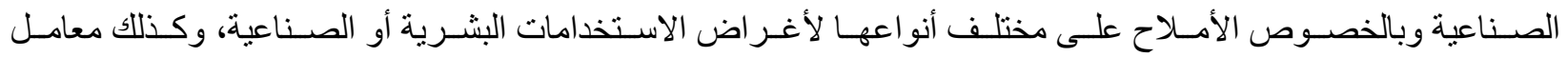
المياة المعدنية الصالحة للشرب.

\section{وصف واقع حال الموقع :}

1ـ الموقع عبـارة عن مـنخفض مـائي يعـاني مـن انحسـار كبير جـاً مـن الميـاة ونسبة تصـحر حيـث يؤشـر معدل انسـاب الماء كيلو منر ونصف عن ساحل البحيرة مقارنة مع حالتها السابقة .

2- بـروز الجـزرات الكلسـية و البلوريـة بشـكل كبيـر ومنتشـر على مسـاحات كبيـرة وبأرتفاعـات على شـكل تـلال و التـي كانت في السابق عبارة عن جزرات صغيرة في البحيرة. [26]

3- انتشـار صـيد الأسـماك مـن قبـل الصـيادين بشـكل كبيـر حيث ينتشـر سـكك الثـانك و الهـامور و هـي أسـماك تـم تربيتهـا في الوقت الحاضر . [9]

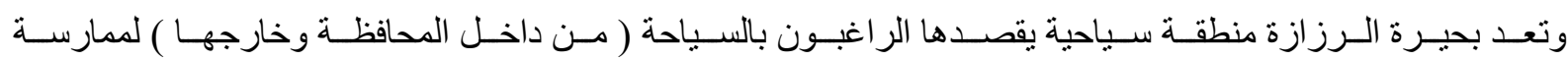
الرياضة المائية ( كالسباحة وصيد الأسماك ) و غير ذلك من الفعاليات الترفيهية . [30] 2- حصـن الأخيضـر : يقـع الحصـن إلـى الجنـوب الغربـي مـن بغــداد بنحـو 102 كـم ، و إلــى الجنـوب الغربـي مـن مدينـة كربلاء على بعد 50 كم على الطريق الذي يربط كربلاء بمدينة عين التمر التي تبعد بنحو 19 كم. ونظـراً لمـا يتمتـع بـه هذا الحصـن مـن فخامـة في البنـاء وروعـه في التصـميم والهندسـة والزخرفـة فقد أصبح مـن أهـم

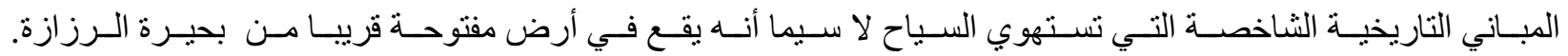




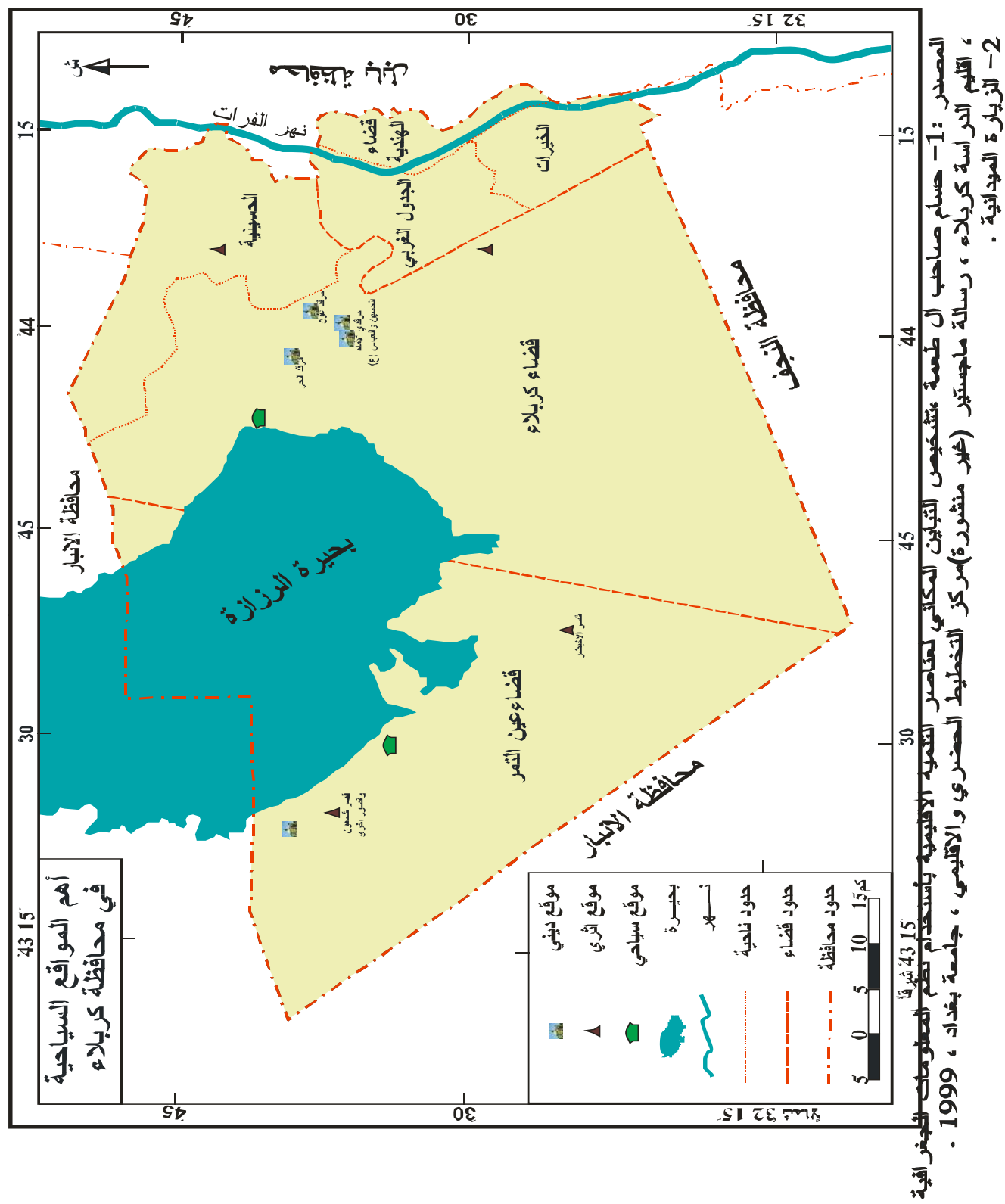

شكل(3): خريطة

وقد أجمع أغلب المؤرخين على أن حصن الأخيضر شيد في العصر العباسي الأول على يد عيسى ابن موسى الذي كان والياً على الكوفة في خلافة عمة أبي جعفر المنصور في القرن الثامن الميلادي ـ [34] حيث يعد حصن الأخيضر واحدا من الحصون الدفاعية التي لاتز ال آثار ها شاخصة تدل على عظمته ،شكل (4) 


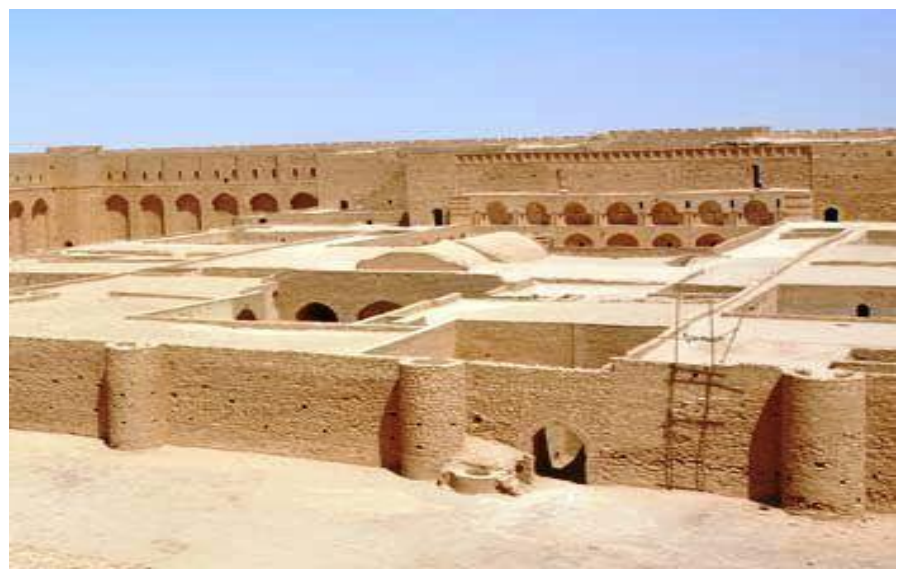

شكل(4): صورة حصن الاخيضرفي محافظة كربلاء

\section{9/3/17 المصدر :التقنها الباحثة بتاريخ}

وهـو مشـــد مـن الحجـر و الجـص ويقوم على مصـطبة طبيعيـة ترتفع عـن مسـتوى الأرض المحيطـة بـه ويحيط بالقصـر

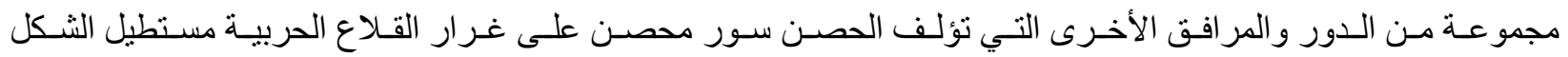

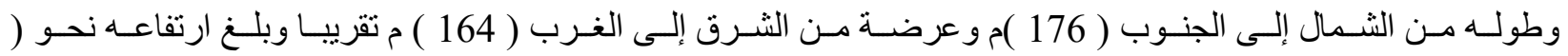
21 ) م، ويضم السور( 10 ) أبراج أخرى قطر كل منهما ( 3.5 ) م ويقـع المــخل الـرئيس للحصـن في السـور الثـمالي، وتنتشــر ضـمن اقلـيم منطقـة الأخيضــرعيون طبيعيـة تقـع

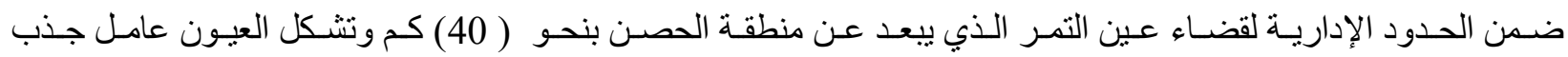
[26] سياحي مهم للسياح و الز ائرين . 3- كهوف الطار :

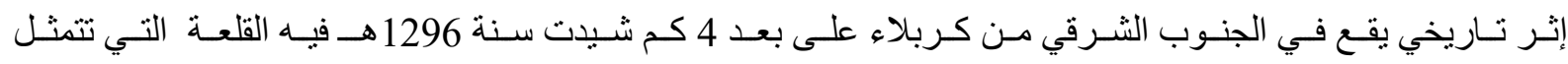
بينايـة ضـخمة تحتـوي على 25 دار و لاتـز ال آثار هـا قائمـة حتى اليـوم. [19] تقـع في منتصـف الطريـق إلـى الأخيضـر فـوق تـل صــري، ولقــ توصـلت بعثـات التنقيـب إلـى وجـود أكثر مـن 2000 قطعـة بعـود تاريخهـا للعصـور الإسـلامية القديمــة وهـي منســوجة بخيـوط ملونــة مصــنو عة مـن الـوبر وشـعر الـــاعز وبعـض القطـع مطـرزة بوجـوه نســائية

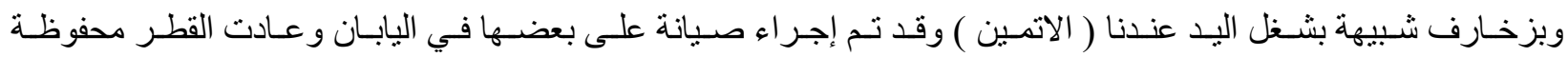
ف19] في صناديق زجاجية ومعبأة بالنتروجين . 


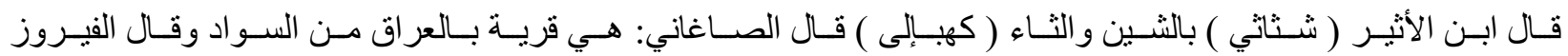
أيادي: شغاثي كهبالى بالعر اق منها موقف حسين بن نصير الضرير النحوي. [1]

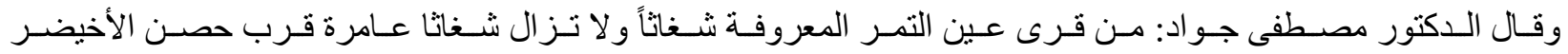

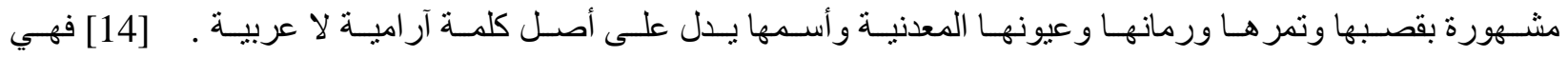

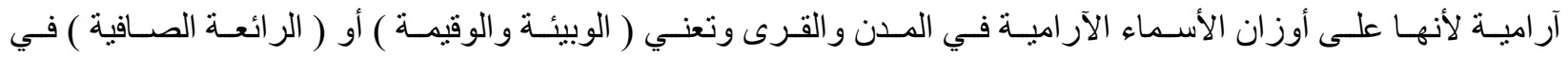

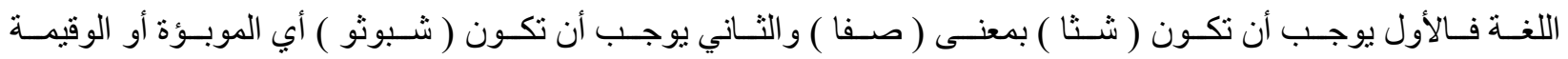

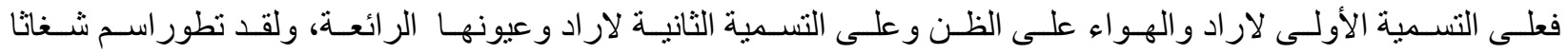

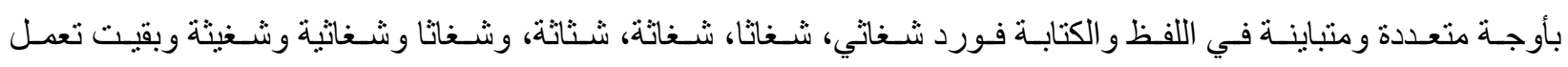
هـذا الألفـاظ الموحـدة القصـد حتى عـام 1938 حيـث تغيـر اســها فسـيت عـين التمـر رسـيا، تقليـدا لمدينـة عـين التمـر التاريخية المندرسة من تلك الألفاظ المتباينة . [24] ثنانياً : الموقع و الحدود:

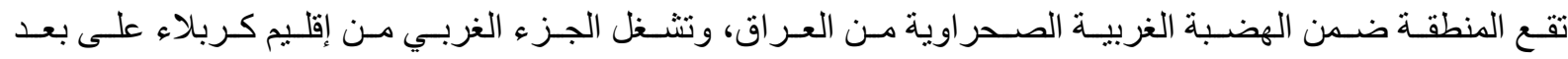

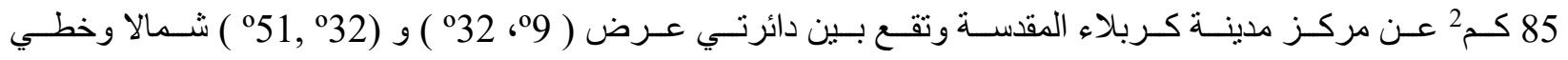
طــول ( 10,43 )و (43,46) شـرقا يحــها مسن الثـرق قضــاء كـربلاء ومسن بـاقي الجهـات فتحــدها محافظــة الانبـار يثــل الاجـز اء الثـــالية مـن منطقـة الدر اســة جـزء كبيـر مـن بحيـرة الـرزازة وكانـت المنطقــة وحـدة إداريــة تعـد ناحيـة

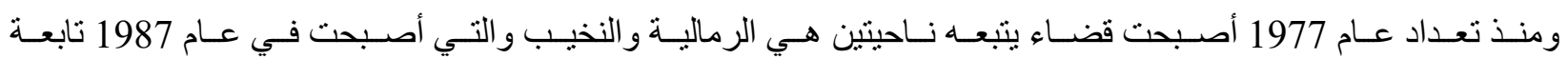
إداريا لمحافظة الأنبار وماز الت المنطقة حتى الآن تعد قضاء وتبلغ مساحته 1956 كم².

تنتشـر في عين التمـر ( شـثاثنا ) عدد مـن العيـون ذات الميـاة المعدنيـة، يخرج المـاء مـن أعماقها ويجري عبـر فتحـات

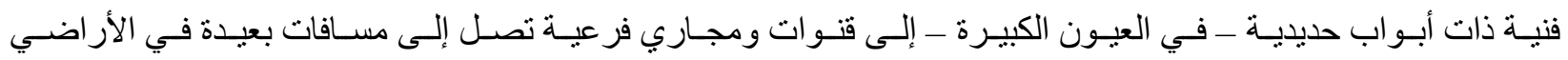


الزر اعيـة ويصـل عمـق المـاء في هذه العيون قر ابـة الأربعـة أمتـار ويزيـد، وكـان يثـاهد فيهـا أنـواع مختلفـة مـن الأسـماك كانت موجودة في مياة العيون قبل أن يمتلئ المنففض بالملح ومن هذه العيون ـ [22]

1

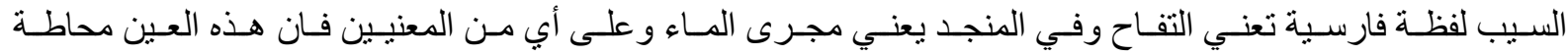

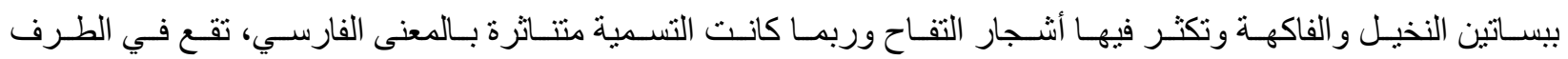
الشرقي من القصبة وهي بيضوية الشكل وطو لها 31 م و عرضها 20 م ،شكل (5)

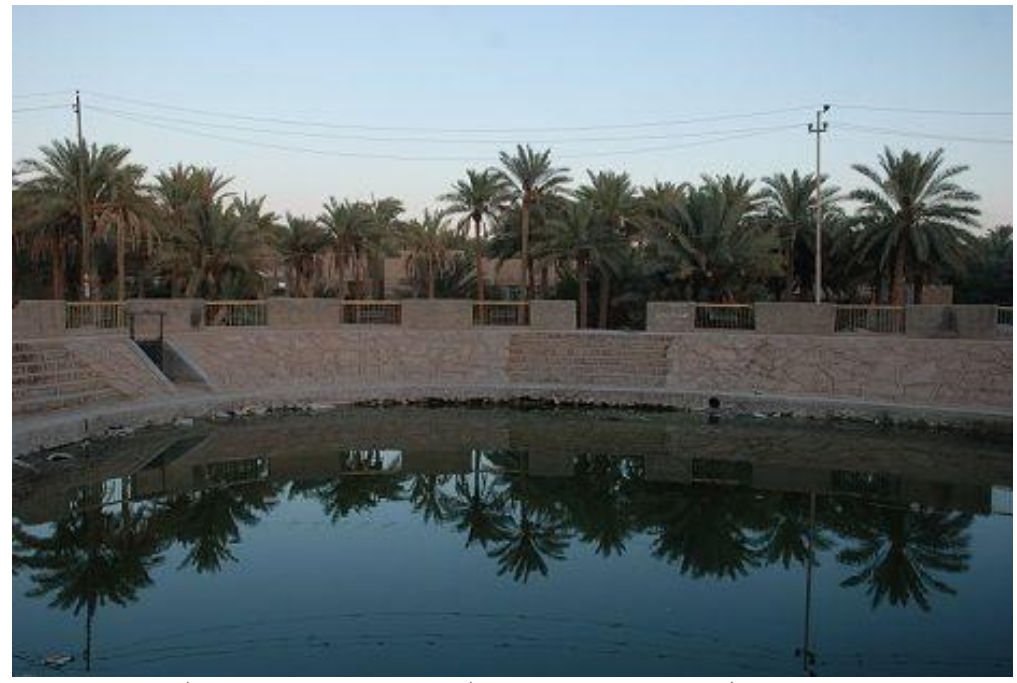

$$
\text { شكل(5): صورة عين السيب في قضاء عين التمر }
$$

2- العين الحمرة:

ســيت بـالحمرة نسـبة إلـى الأرض المسـماة الحمـرة التـي تقـع فيهـا العـين والعائـدة للســادة (البوضـوي) وتقـع شـرقي العين الكبيرة وبالقرب منها ونتألف من حفرتين ويجري الماء عبر فتحات صغيرة إلى البساتين . 3- العين الكبيرة:

وتســى أيضــا العـين ( الزرقـة ) وذلــك لعمـق المـاء فيهـا فيظهـر بلــون أزرق ويسـميها العـرب أو البـدو( غربيـد ) وذللك لسرعة جريان الماء المتدفق في مجاريها

\section{4- عين الضابط:}

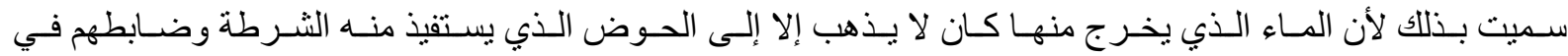


صغر اسمها لصغر مساحتها وقلة مياهها وهي تعود إلى ورثة الحاج رحمن البنا

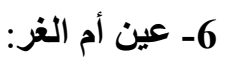

يقـال أن سـبـ التســية يعـود إلـى أن مجموعـة مـن الأغنـام الغـر الجميلـة تتـردد عليهـا وترتـوي بـين مياههـا وهـي

وسبب التسمية يعود إلى وقو عها قرب مرتفع وأطلال قصر ( ابو جبل ) المتدرس و هي صغيرة قليلة الفائدة.

كانـت عين التــر ( شـغاثنا ) مركز الناحيـة ومـا تـز ال ولـم تكن المدينـة صـورة مـن صـور المدينـة حتى عـام 1942م، حيث بدأت يد الإعمار إليها فشيدت الدور والمباني وتحت الحوانيت والمحلات و المقاهي .

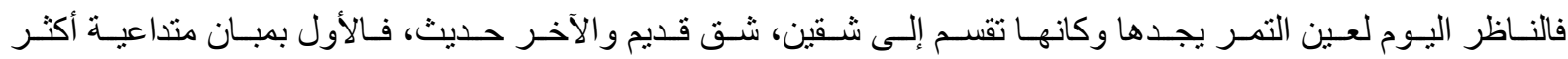

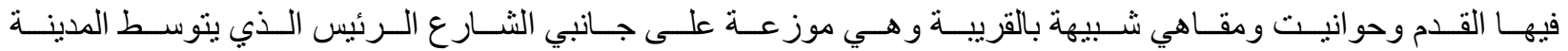
ويتوسـهها المسـد الـذي شـيده المحسن الحساج حسـين المعـروك و البهيهـاني عـام 1888م [17]، وهـو يتـألف مـن بهـو

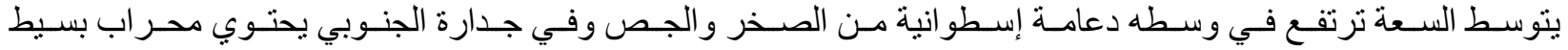

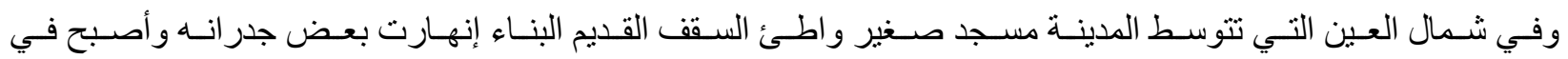
عداد الأبنية المهجورة فنيدت الكازينو مكانه .

\section{وتضم عين التمر العديا من القصور الآثارية منها: [27]} 1 قـصر العين:- سمي بهذا الاسم لوقو عه على أكبر عيون شغاثا. 2_قصر ال حردان :- انفصل قسم من عشيرة ال حردان - سكنة قصر العين وشيدو ا قصر ا مستقلا باسم العشيرة. 3_ قصر ثامر : سمي نسبة إلى مؤسسة ثامر ال رميد شيده قبل ما يقارب 120 سنة.

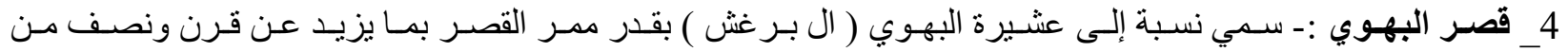
السنين ويقع في الجزء الشمال الشرقي من عين التمر. 
5ـ قصـر شـمعون : ســـي بهـذا الاسـم نسـبة إلى شـمعون بـن جـابر اللخــي أحـد رجـال الـدين المسـيحيين شـيد في وآخـر

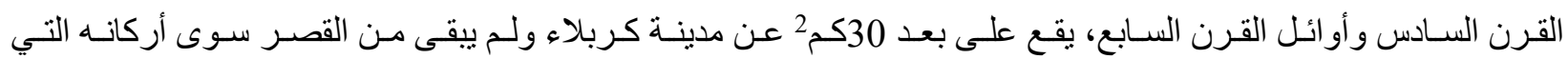
يبلغ ارتفاعه 15 منر. الطبوغرافية : تمثل الترب الصحر اوية معظم أجزاء الدراسة وتمتاز بما يلي: 1 - إنبساط سطحها . 2- انحدار ها التدريجي من الجنوب الغربي نحو الثمال الثرقي. 3- تتخللها مظاهر متنو عة من المنخفضات والتموجات. 4- عو امل باطنية عملت على خفض بعض الأماكن الو اقعة إلى الغرب منها (كمنخفض الرزازة). 5- يتقطع سطح الهضبة بو اسطة عدد من مجاري الأودية التي تنتج الانحدار العام. 6- تصريف الوديان محدود جدا بسبب النفاذية العالية لطبقات الرمال و الحصن التي تجري فوقها المياة. ينقسم سطح المنطقة إلى ثلاثة أقسام :

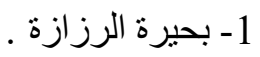
2- 12- منطقة المراوح الفيضية المجاورة لبحيرة الرزازة. 3- الهضبة الغربية الصحر اوية التي تشكل أكبر قسم لسطح منطقة الدراسة. المنــاخ :- إن منطقـة الدر اسـة هـي جـزء مـن الصــحر اء ومناخهـا لـه مو اصـفات المنــاخ الجـاف، حيـث نتفــاوت درجـات

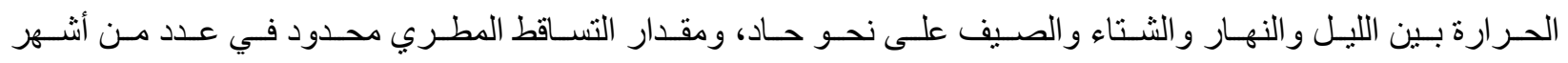

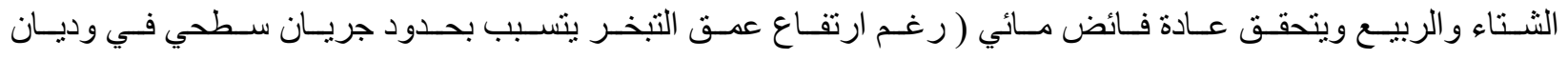
الابــض و الحــف خاصــة نتيجـة لطبيعـة توزيــع التسـاقط ) الـذي يتحقـق عـادة على شـكل زخـات كثيفـة إلا أن مسددها قصـيرة، أمـا سـر عة الريـاح تزداد في فصلي الربيع و الصـيف ممـا يـل على كثرة العو اصـف وارتفـاع نسب التبخر مـع تز ايد هذه السرعة للرياح. [9] 


\section{ثانياً : استراتيجية تطوير المحميات الطبيعية في محافظة كربلاء}

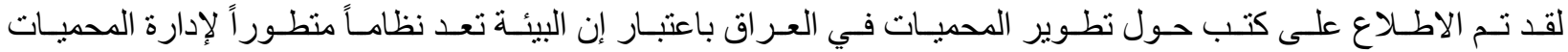
فـي العـر اق ونظـر اً للتهديـدات التـي تو اجهـه الـنظم البيأيـة فـي العـراق رشـحت اللجنـة الوطنيـة لدر اســة المواقـع الطبيعيـة

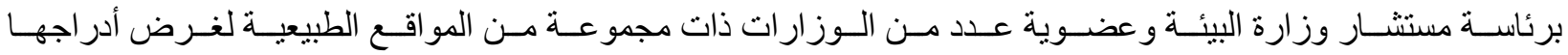
ضــن الحمايـة الطبيعيـة منهـا أهـوار جنـوب العـر اق وبحيـرة الـرزازة وبحيـرة سـاوة وهـور الـدلمج ومواقع أخـرى عديـدة

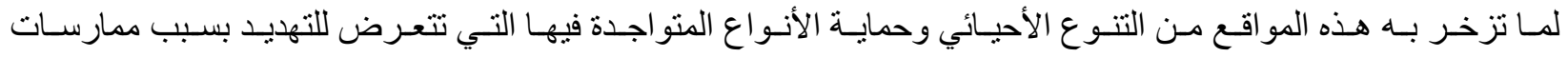

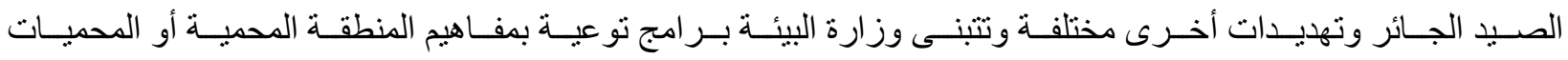
الطبيعية بشكل عام من أجل الاستفادة من القو اعد التي ممكن تحقيقها من جانب سياحي وطبيعي .

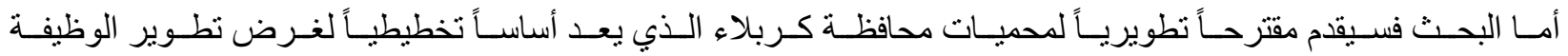
السياحية للمحميات وتتضمن استر اتيجية التطوير التي يعتمدها البحث مايلي : إستراتيجية التطوير التي يقترحها البحث :

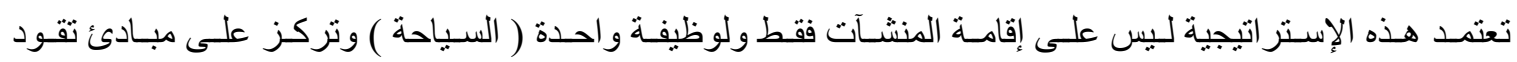
إلى تتفيذ إستر اتيجية متعددة الأبعاد و الوظائف أهمها :

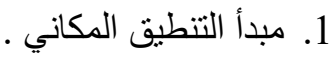
2. بدأ التنطيق الزماني . 3. مبدأ التنطيق القطاعي . 4. بدأ التنطيق الاستثماري والإداري . 5. مبدأ المشاركة الشعبية.

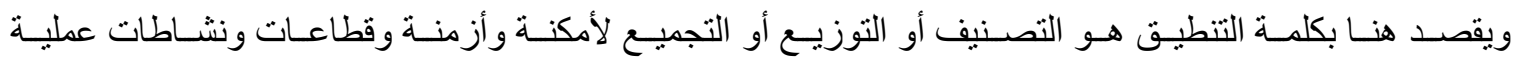
التطوير التي تتضمنها الإستر اتيجية، ويمكن توضيح هذه المبادئ كالآتي :

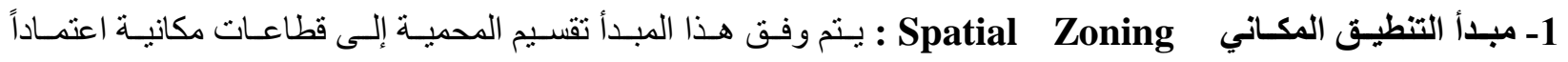
على درجة تدخل الإنسان على ضوء ثلاثة مفاهيم :

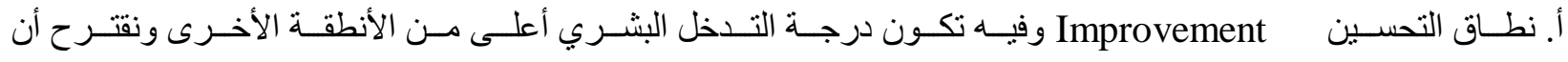
ينحصـر هذا القطـاع في المنطقـة القريبـة مـن الثـار ع العـام الذي يـربط محميـة عين التمـر التي تقع على بعد 65-85 كم عن مدينة كربلاء و التي بربط بينهما شار ع مبلط. 


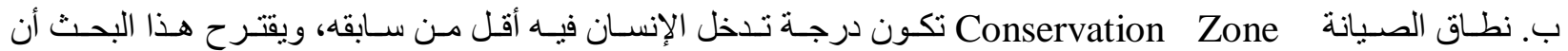

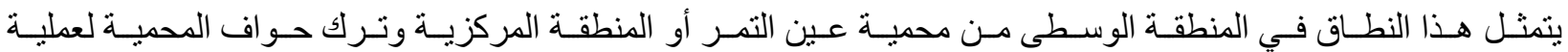

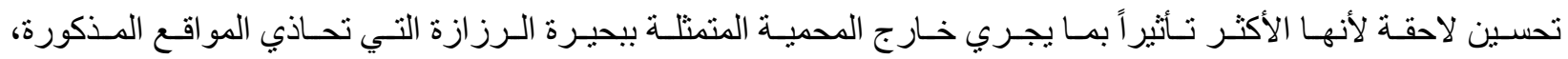

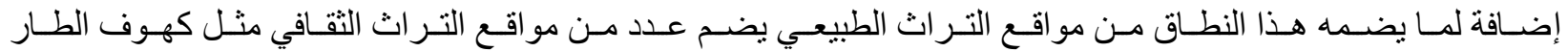
وقصر خيضر . ج. نطـاق الحمايـة Protection Zone وهو الذي يكون تـخل الإنسـان فيـه عند حدوده الدنيا الضـرورية ويتلاءم مـع

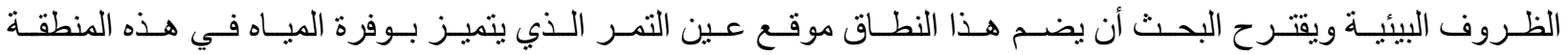

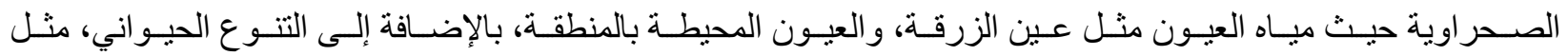
طيور الخناق وطيور السلوى. و هنا لابد من إعادة المسح الثامل للمحمية لتحديد المدى المكاني لكل نطاق.

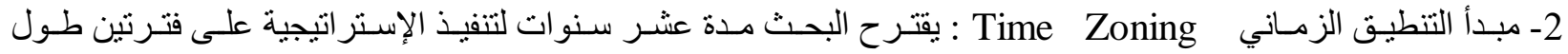

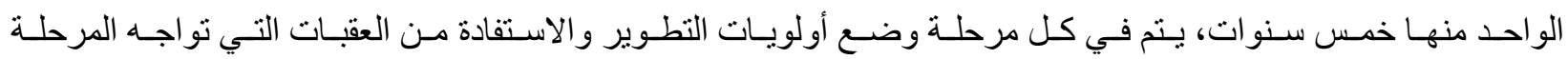

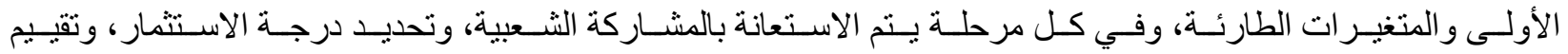
الأثر البيئي لهاو الطاقة الاستيعابية، والمنشآت والكو ادر المطلوبة، ونوع التمويل .

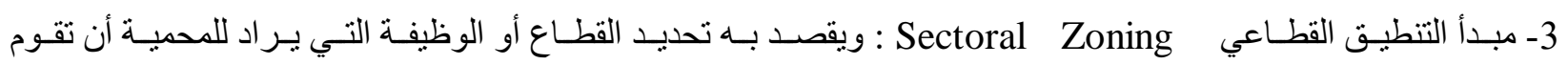
بهـا وتـدار مـن أجلها، وكمـا ورد فـي الصـفحات السـابقة وكمـا هـي خصـائص محميـة بحيـرة الـرز ازة التـي تضــم إمكانـات

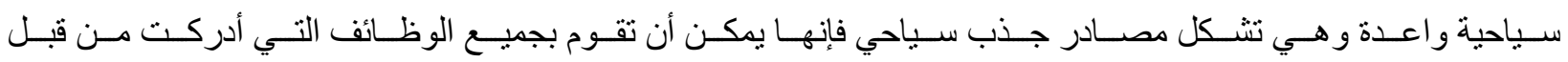

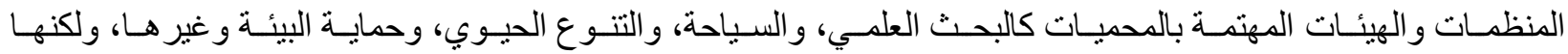

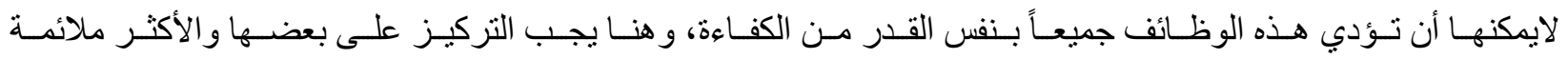
وجدوى اجتماعية و اقتصادية وبيئية، وتمرحل تنظيم هذه الوظائف.

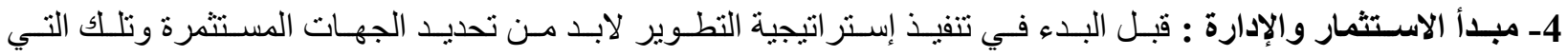
تـدير المحميـة، ويفضــل مـن وجهـة نظــر البحــث أن تكـون الجهـة المسـتثرة و المـديرة للمحميـة أجنبيـة بالكامـل للمرحلــة

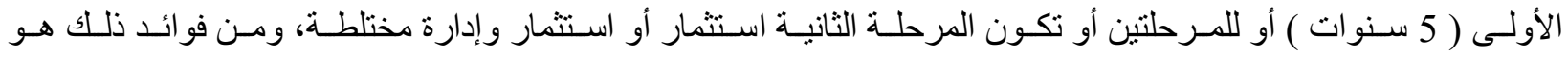
الـتخلص مـن البيروقر اطيـة الإداريـة المحليـة وعائديـة المحميـة، ثـم الاسـتفادة فـي تكـــين وتـدريب رديـف محلـي خـلال

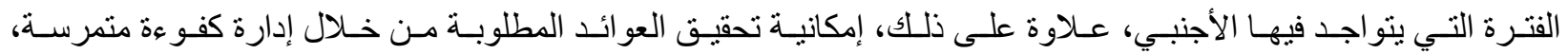




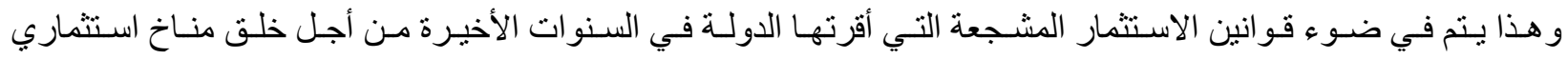

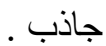

6- مبـدأ المشـاركة فـي صـنع القـرار: لقـد أدرك العـاملون في حقل المحميـات أن على المجتمعـات المتـأثرة بهـا أن تكـون أكثــر انخر اطــاً فـي تخطـبط و إدارة المحميـات إذ لا يمكـن إقصــاء السـكان المحليـين وتجــاهلهم مـن قبـلـ الحكومــات الإقليمية أو المركزية عند إنشاء المناطق المحمية ، كما لا يمكن تهميشهم في عملية التخطيط.

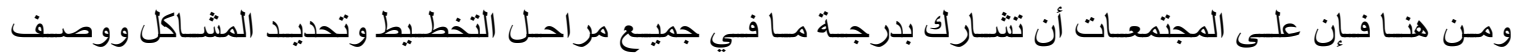

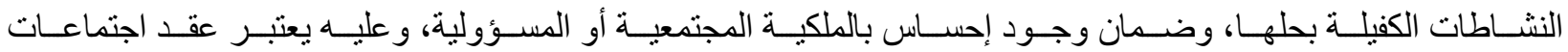

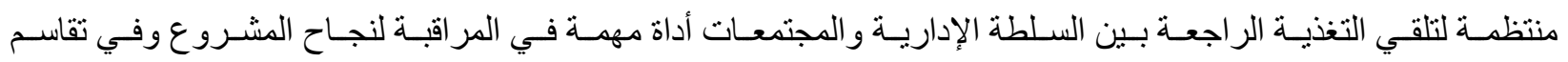
الأفكـار و الخبـر ات لحـل المشــاكل، ومـن المهـم وجـود شـفافية فـي اتخـاذ القـرار ات وضــــان إدر الك أكبـر عـدد ممكـن مـن الأطر اف المعنية لما يحدث.

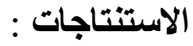

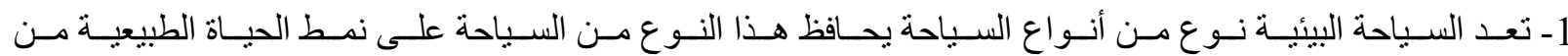
المحميات النباتية والحيو انية ويعمل على إيجاد تطور اقتصادي في الإقليم الذي تقام فيه.

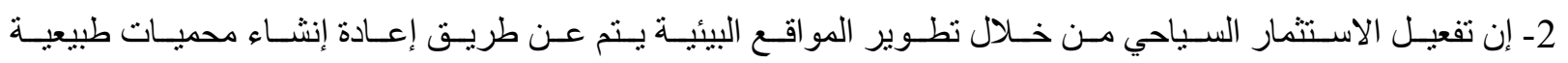
سيؤدي حتماً إلى تفعيل النشاط السياحي بصورة كبيرة .

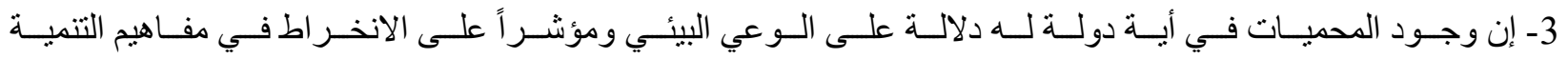

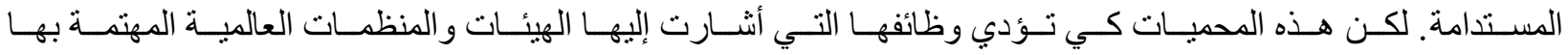

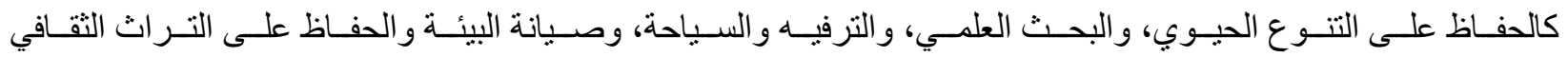
و غير ها، لابد من وجود ضو ابط لإنشائها و إدارتها. 4- إن محميــات محافظــة كـربلاء تتمتـع بمعـايير إنشـــاء المحميـة إلا إن الإدارة غيـر الكفـوءة بالإضــافة إلــى الظــرف الأمنـي الــي يعيثـهـ العـر اق فـآل وضـعها عبـر الـزمن إلـى اختفـاء أيــة وظيفـة لهـا، حيـث اختفـت الحيوانـات البريـة التـي كانـت فيهـا، وتحولـت بعـض منشـآتها إلـى ورش تـؤجر للأهـالي، وتـدهورت حالــة بعضض المبـاني فيهـا، و أخـــ الاعتـــاء

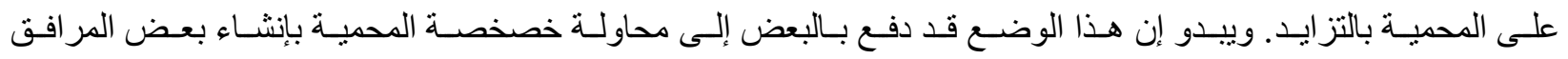
فيهـا و اسـتغلالها تجاريـاً. كل هـذه الأمـور دفعـت البحـث إلى أن يُقدم إسـتر اتيجية تطويريـة تعتمـد على مبـادئ عامـة تقود 


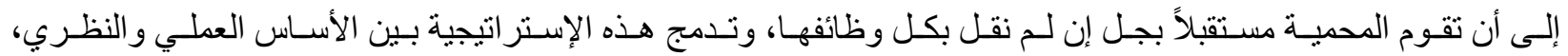
وبـين الواقـع و المطلـوب، و التي يمكن أن تشـمل عـدة خطط Plans وبـر امج Programs تفصيلية لتنفيـها مسن أجلـ إعادة الحيوية إلى محميات محافظة كربلاء . التوصيات :

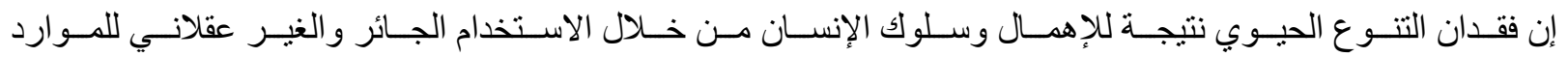
الطبيعيـة أدى إلـى تـدهور وتلـف العديـد مـن المـوارد الطبيعيـة ( النباتيـة والحيو انيـة ) لـذا فـان تأسـيس و إدارة المحميـات الطبيعة يعد من أهم طرق المحافظة على التنوع الاحيائي لذا توصي الدراسة بما يلي: 1- تبـادل الخبـر ات مـع الـدول المجـاورة و التـي لهـا نظـم بيئيـة مقاربـة في مجـال المحميـات الطبيعيـة لتبـادل المعلومـات و الخبرات حول تأسيس وادارة المحميات الطبيعية. 2- إيجـاد جهـة مختصــة فـي إدارة المحميـات عـن طريـق إقامـة ادارة مركزيــة وتعطـي كافـة الصــلاحيات لتســهيل عملية الإدارة و الإشر اف و إنهاء الازدو اجية في الإدارة .

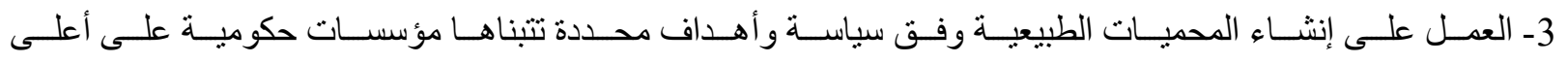
مسـتوى، هـذه السياسـات و الأهـداف تثــمل الحفـاظ علـى إنتاجيـة التتـوع الحيـوي و الحفـاظ على التبـاين فـي المـوارد الطبيعية. 4- يجـب انتخـاب فريـق لتخطـيط عمليـة اختيـار المحميـات على أسـاس علمـي وإجـر اء مسـوح شـاملة بقدر المسـنطاع للتعرف على المواقع التي تستحق الحماية .

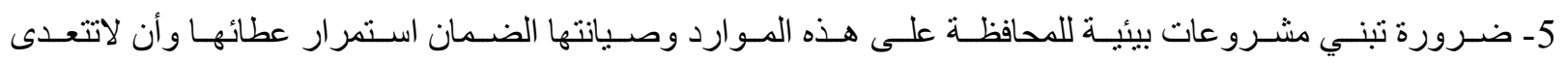
طبيعة المشرو عات التتموية المعتمدة وحجمها الحمولة المتو اضعة إلى هذه الموارد الهشة. 6- إعـداد كـو ادر متخصصــة فـي إدارة المحميـات عـن طريـق إقامـة الـدور ات و النـدو ات العلميـة و الفنيـة و الاسـتفادة مـن خبرات الدول المتقدمة.

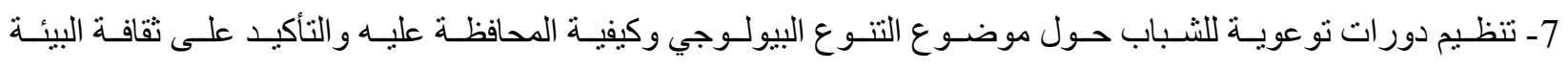

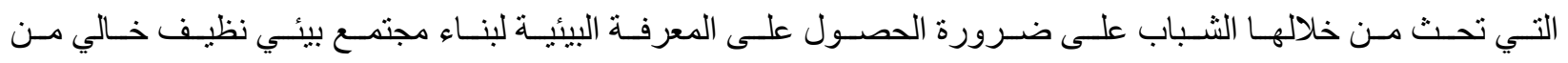
التلوث. 


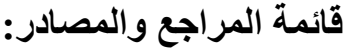

$$
\text { [1] ابادي ،فيروز، القاموس المحيط ، ط2 ،دار احياء الكتب ، بيروت ، (1960). }
$$

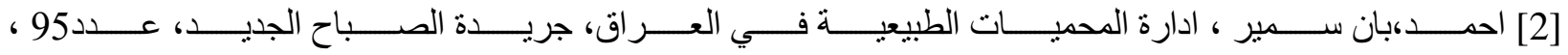

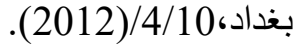

[3] ال طعمة،حسام صاحب حسون، تشخيص التباين المكاني لعناصر التنمية المكانية باستخدام نظام المعلومات

[4] الجغر افي ، اقليم كربلاء ، رسالة ماجستير ، مركز الخطيط الحضري والاقليمي، جامعة بغداد ، (1998)

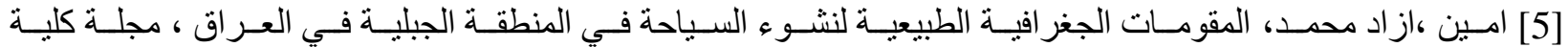
التربية ، جامعة البصرة ، المعدة (1979 ) ).

[6] الانصــاري ،رؤوف محمـد علـي، السـياحة البيئيـة في العـر اق ودور هـا فـي التنميـة والاعمـار ، ط1،مطبعـة هـادي بـرس

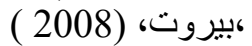

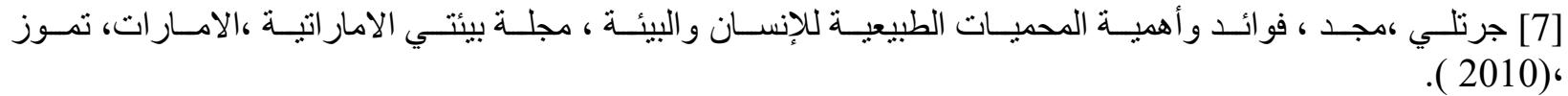

[8] جودت ،ندى شاكر ، اهو ار غرب العراق ،مجلة الجمعية الجغر افية العر اقية،عدد 53 ، (2002)

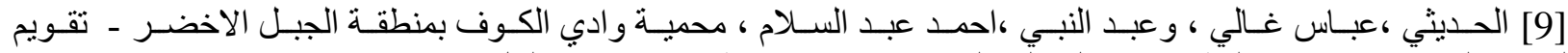

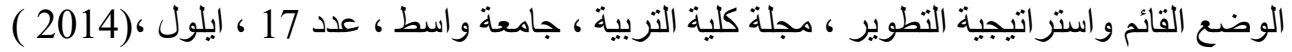

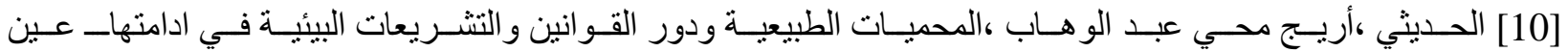
التمر حالة در اسية،رسالة ماجستير،مركز التخطيط الحضري والاقليمي ،جامعة بغداد، (2009 )

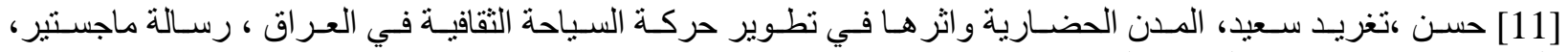
كلية الادارة والاقتصاد ، الجامعة المستنصرية ، (1997)

(2001)، [12 حسن ،قتحية محمد ، مشكلات البيئة ، مكتب المجتمع العربي للنشر والتوزيع ، الاردن ، عمان

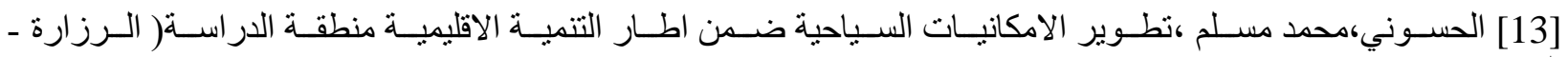

الحبانية )

رسالة ماجستير،مركز التخطيط الحضري والاقليمي ،جامعة بغداد ، (1990)

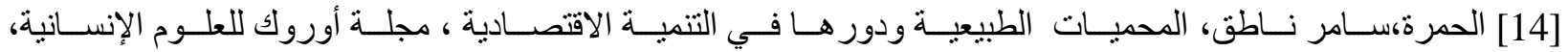
العدد الثالث و العشرين ، هيئة السياحة،بيغداد، (2012)

[15] الخليلي ،جعفر ابر اهيم، موسوعة العتبات المقدة ، قسم كربلاء ج1 ، ط1 ، دار المعارف ، بغداد ، (1960). [16] الخضيري،محسن احمد ، السياحة البيئية ، مجموعة النيل العربية ، ط1 ، رقم الايداع 16498 ، (2005 ). [17] دعيس ،يسرى، المحميات الطبيعية والتوازن البيئي ،الاسكندرية للنشر و التوزيع ،مصر ، (1999 ). [18] شـمطو ،سـمير خليـل، دليـل كـربلاء السـياحي ، اصـــار رابطــة الفنـادق و المطــاعم السـياحية ، كـربلاء المقدسـة ، (2008) ،

(2009)، [19] [الثيخ حسين ،عادل ، البيئة مشكلات وحلول ، الاردن ، عمان

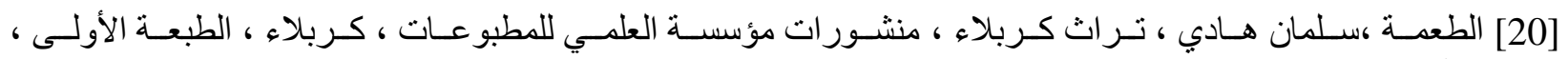
مطبعة ،النجف،(1964). 


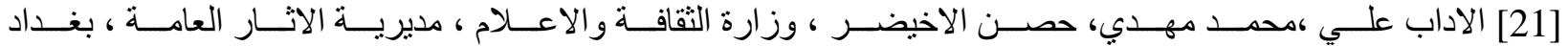
‘(1969)،

[22] علو ان ،علاء كامل ، مدونة البيئة العر اقية ،وزارة الثقافة ، هيئة السياحة، 2008/10/1). [23] عيسى ،ارزوقي، مختصر جغر افية العراق ، المطبعة السريانبة الكاثوليكية ، سوريا ، دمثق(1922).

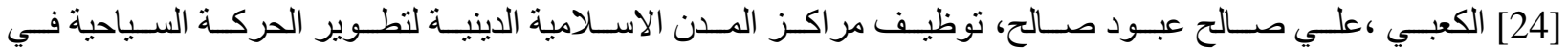
(1998)، العر اق ، منطقة الدر اسة كربلاء ،رسالة ماجستير ، كلية الادارة و الاقتصاد ، الجامعة المستتصرية الاينة [25] الكليدار ، عبد الجواد ، تاريخ كربلاء ، مطبعة كربلاء ، مطبعة المعارف ، (1960). [26] مدلول ،عو اطف ، جريدة الصباح ، مركز الصباح للار اسات الاستر اتيجية ، بغداد ، (2012). [27] المسعودي ،رياض محمد علي ، مجلة المعرفة ، العدد الخامس والاربعون ، (2008) [28] المطيري ،مهنا رباط، جغر افية مدينة النهرين، بغداد، مطبعة الزمان، ج3، (1964)

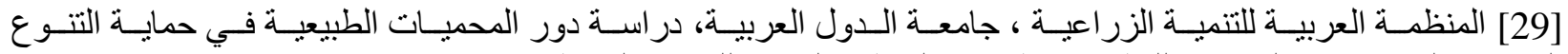
الحيوي والمشروعات المقترحة للتطوير ، طبع في المنظمة العربية للتنمية ،الخرطوم، لاعة (1990).

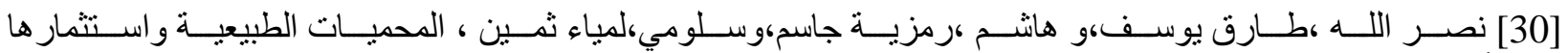
سياحياً في العر اق، وزارة الثقافة ، هيئة السياحة ،قسم الدراسات ورة والتخطيط، (1999)

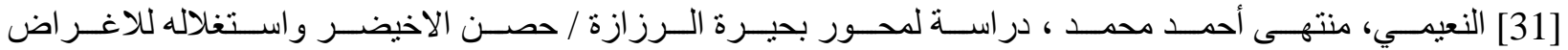
السياحية ، رسالة ماجستير ، مركز التخطيط الحضري والاقليمي ، جامعة بغداد ، (2000 ).

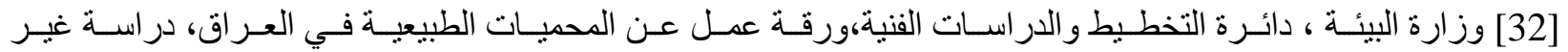
منشورة ،العراقهبغداد، (2011)

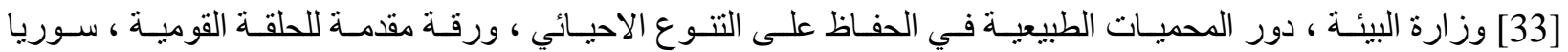

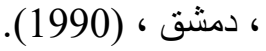

[34] وزارة البيئة ، دائرة بيئة بغداد ، قسم التنوع الاحيائي ، الو اقع البيئي للتنوع الاحيائي في العراق ، (2006) .

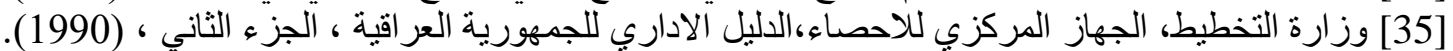

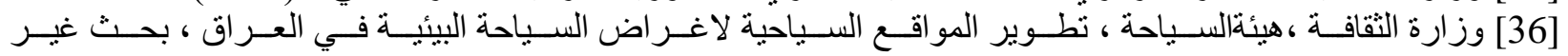

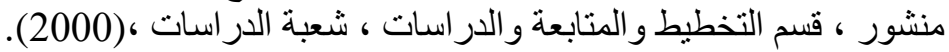

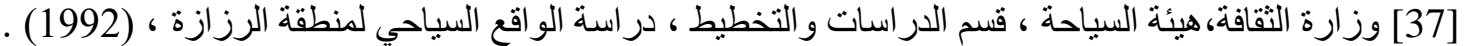

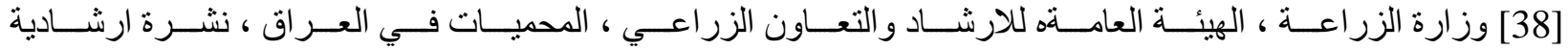
.(2004)، 